\title{
Climate and crops in northwest Portugal (1798-1830): A glimpse into the past by the light of two Benedictine diaries
}

\author{
Luís Pedro Silva
}

KEYWORDS: harvest, climate, extreme weather events, weather diaries.

JEL CODES: Q540, Q150, R110, Q250.

his paper aims to assess the impact of hydrometeorological phenomena on agri-
cultural production in northwest Portugal, from the end of the eighteenth cen-
tury through the first three decades of the nineteenth century. The study analyses and discusses two recently discovered weather diaries from the agricultural region of Entre-Douro-e-Minho, in northwest Portugal (along the Atlantic coast of the Iberian Peninsula, southwest Europe). These written records were kept by Benedictine monastic communities, which used to own large farms in this region. As sources, they provide systematic data concerning weather conditions from 1798 to 1830, along with indications of the impacts on agricultural production in the region. For data analysis, we developed indices for precipitation, temperature, and agricultural production, converting qualitative data into categories of intensity. The results point to important thermal and rainfall anomalies that significantly impacted crops (in terms of yield and harvesting times) and food prices. 


\title{
Clima e colheitas no Noroeste de Portugal (1798-1830): Uma visão do passado à luz de dois diários beneditinos
}

\section{PALAVRAS-CHAVE: colheitas, clima, eventos meteorológicos extre- mos, diários meteorológicos.}

\author{
CÓDIGOS JEL: Q540, Q150, R110, Q250.
}

$1 \begin{aligned} & \text { o presente trabalho procuramos avaliar o impacto dos fenómenos hidrome- } \\ & \text { teorológicos na produção agrícola do Noroeste de Portugal, entre o final do } \\ & \text { século XVIII e as três primeiras décadas do século XIX. O estudo parte da aná- }\end{aligned}$ lise de uma fonte de particular interesse meteorológico: os "dietários". Produzidos por várias comunidades monásticas beneditinas, detentoras de grandes propriedades agrícolas no Norte de Portugal, os dietários fornecem informação sistemática sobre os estados do tempo no periodo finissecular e nas primeiras décadas do século XIX, assinalando, em simultâneo, o impacto deste tipo de fenómenos na produção agrícola da região. Para a análise da informação presente nos dietários, recorremos à construção de índices de precipitação, temperatura e produção agrícola, atribuindo a diferentes expressões de natureza qualitativa uma determinada categoria de intensidade. Os resultados sugerem a ocorrência de importantes anomalias térmicas e pluviométricas, as quais tiveram impactos significativos nas culturas agrícolas (em termos de rendimento e duração da colheita) e nos preços dos alimentos.

Received: 2019-03-03 - Revised: 2020-02-02 - Accepted: 2020-03-14

Luís Pedro Silva [orcid.org/0000-0002-8837-0393] is researcher at the Transdisciplinary Research Centre "Culture, Space and Memory" (CITCEM), University of Porto (Portugal). Address: Faculdade de Letras da Universidade do Porto, via Panorâmica, s/n, 4150-564 Porto (Portugal).E-mail: pedrosilva1099@ hotmail.com 


\section{INTRODUCTION}

Climate change has emerged as one of the major environmental challenges of our time, with profound impacts on several areas of society. Considering the risks to communities, especially the more vulnerable ones, global climatic variations and extreme weather events stand as some of the most relevant topics of discussion on sustainable development, spatial planning, and natural disaster risk management, deserving great attention from governments, academics, and public opinion (Alcoforado, 2008). Created in 1988, by the World Meteorological Organization (WMO) and the United Nations Environment Program (UNEP), the Intergovernmental Panel on Climate Change (IPCC) has warned to the significant vulnerability and exposure of human and natural systems to climatic changes and extreme weather events (e.g., storms, floods, droughts, heat waves, and cold spells), based on numerous scientific evidences and on a long-term series of meteorological variables (Stocker et al., 2013).

Within this framework, many scholars stress the importance of historical data for the construction of a solid and structured knowledge about global climate changes. These efforts can contribute to improve environmental governance and lead to the adoption of a transgovernmental and multisectoral prevention strategy (Mann et al., 2000). At the same time, the study of climatic variability and extreme weather events, on a secular time scale, allows for a better understanding of how environmental forces affect human societies in many important sectors, such as health, agriculture, and food security, as well as water supply, transportation, energy, ecosystems, among others (Fagan, 2002; Parker, 2014; Alberola, 2014; Pfister, 2015; Le Roy Ladurie, 2017).

Recent advances in Historical Climatology, in Portugal, gave rise to a more precise and detailed picture of climatic variations and extreme weather events occurred in the past few centuries (Alcoforado et al., 2000; Nunes, 2003; Taborda, Alcoforado \& Garcia, 2004; Oliveira, 2007; Alcoforado et al., 2012; Fragoso et al., 2015; Amorim, Silva \& Garcia, 2017; Fragoso, Carraça \& Alcoforado, 2018; Silva, 2019). These developments are highly relevant for a better understanding of global climate change, more specifically, in southwestern Europe (Luterbacher et al., 2004; Pauling et al., 2006; Rodrigo \& Barriendos, 2008; Camuffo et al., 2010; Camuffo et al., 2013; Oliva et al., 2018). However, there is still a long way to go in this area of research, in Portugal. The complex temporal and spatial distribution of climate variables stresses the need to increase the number of evidences in order to make a more precise reconstruction of these phenomena in the pre-instrumental period (i.e. prior to the 1850 's), at local, regional, and even national level, as well as to improve the knowledge about the effects of these natural events on agricultural, forestry, and fisheries systems throughout history (Silva, 2019). 
In most countries, including Portugal, systematic and continuous meteorological instrumental observations began only in the middle of the $19^{\text {th }}$ century (Ferreira, 1942a). Before that, to obtain information about past climates we need to use other data sources. During recent decades, scholars have used a very broad range of natural proxies (tree rings, fossil pollen, ice-cores, corals, moraines, boreholes, etc.) and documentary evidence (chronicles, diaries, letters, economic records, newspapers, etc.) for reconstructions of preinstrumental climate (Brázdil et al., 2005).

Weather diaries are among such sources. They are particularly useful because they give us a very accurate description of the weather and related phenomena. At least since the Early Modern Period, professionals of several kinds (astronomers, priests, physicians, farmers, seamen, among others), kept a weather diary over several weeks, months, or even years, basing their notes exclusively on a direct visual observation. Weather diaries were kept for several reasons, from simple curiosity to concerns about the influence of these phenomena on public health, agriculture, or navigation ${ }^{1}$. Qualitative daily weather records are thus a very valuable research tool to study climate history, especially when available in long series and when supported by other data. Many relevant examples of weather diaries have been found all over the world that helped the reconstruction of past climate in regions such as north-western Europe (Metzger \& Tabeaud, 2017; Sanderson, 2018), central Europe (Pfister et al., 1999; Bokwa et al., 2001; Brázdil \& Kiss, 2001; Brázdil et al., 2003; Brázdil, Çernuşák \& Eznícková, 2008; Brázdil et al., 2019), southern Europe (Raicich, 2008; Fernández Fernández et al., 2014; Domínguez Castro, García Herrera \& Vaquero, 2015), North America (Druckenbrod et al., 2003), eastern Asia (Walsh, Glaser \& Militzer, 1999; Hirano \& Mikami, 2008; Zhang et al., 2013), and Oceania (Lorrey \& Chappell, 2016).

In Portugal, weather diaries are very scarce. The few ones that exist mostly accompany the early meteorological measurements and cover a very short period of time (Alcoforado et al., 2012). In this context, it is particularly interesting the analysis and discussion of two recently re-discovered weather diaries, written in the agricultural region of Entre-Douroe-Minho, in the northwest of Portugal (Western Atlantic coast of the Iberian Peninsula, in the southwest of Europe). These sources, produced by Benedictine monastic communities, that used to own big farms in this region, provide systematic data concerning weather conditions between 1798 and 1830, and are supplemented by a number of phenological and agricultural production records.

1. Logbooks are a specific type of weather diary and they provide precious data about weather and atmospheric circulation in the oceans. See GARCía HERRERA et al. (2005) and BARRIOPEDRO et al. (2014) for a review articles. 


\section{FIGURE 1}

The Entre-Douro-e-Minho region

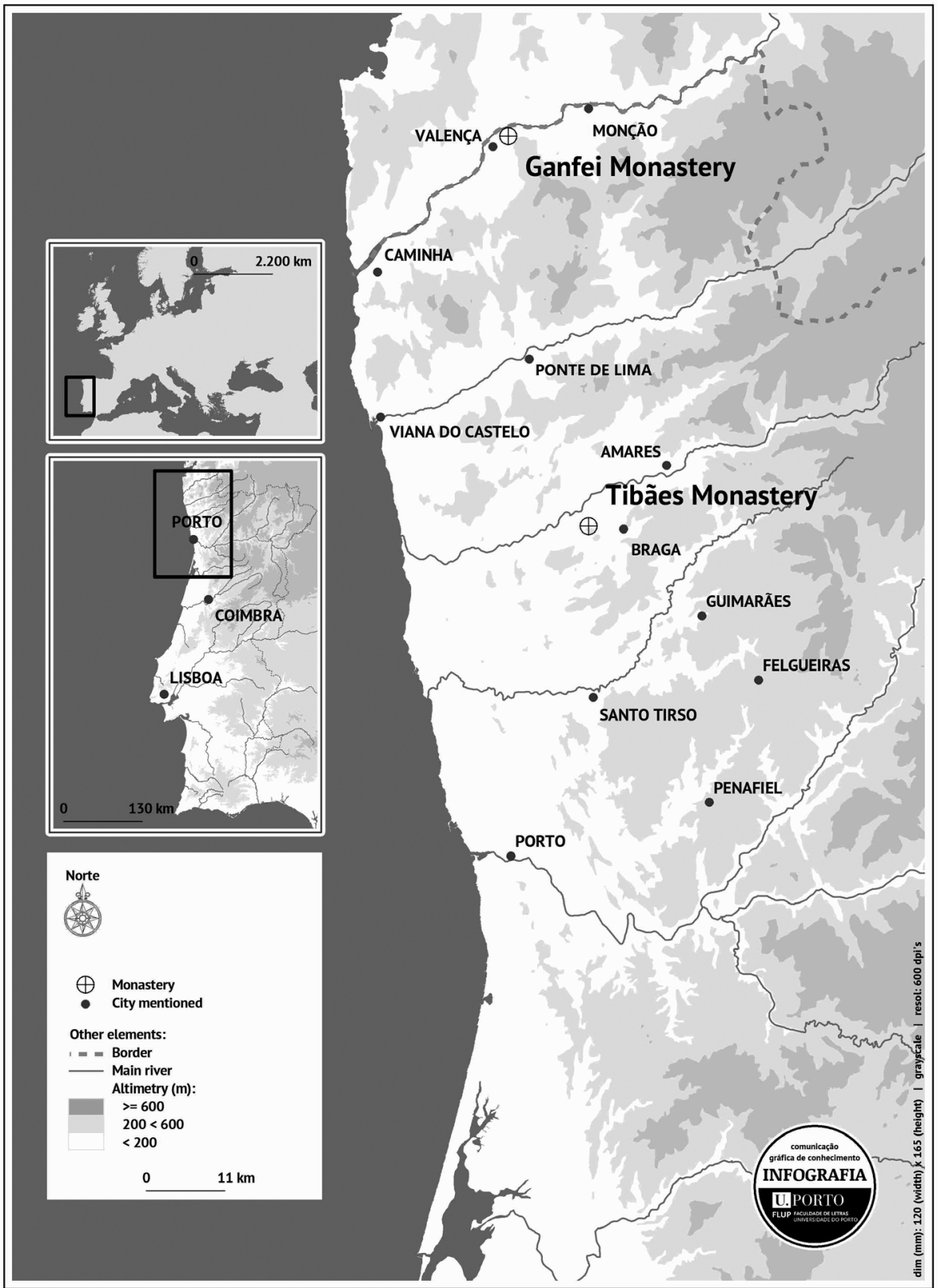

Note: the figure includes the names of the Portuguese locations mentioned in the text.

Source: CAOP, IGP, 2004; cartography: Miguel Nogueira, 2019. 
Based on these two sources, we intend to: define opportunities and problems concerning the use of documentary evidences in Historical Climatology in Portugal; reconstruct climatic variations and extreme weather events in the northwest of Portugal, during the period 1798-1830, in order to help complete the spatial coverage of past European climate within the so-called Little Ice Age ( $14^{\text {th }}-19^{\text {th }}$ centuries); and assess the impacts of meteorological phenomena on agricultural activity in the geographical area here studied.

\section{GEOGRAPHICAL FRAMEWORK}

As we can see in Figure 1, the northwest of Portugal, historically known as EntreDouro-e-Minho (a historical province between the Douro and Minho rivers), presents a rugged relief, crossed by watercourses, defiles, and narrow valleys, with increasing altitudes from the coast to the mountains inland, constituting, according to several authors, a large amphitheatre facing west. Gravitating around Braga, Guimarães, and Porto (which is today the country's second largest city in terms of population and economic importance, after the capital, Lisbon), this region is marked by a rich vegetation, with species of deciduous trees, typical of the Atlantic Europe (Medeiros, 2005).

At present, the Entre-Douro-e-Minho region exhibits a temperate Mediterranean climate with maritime influence. The annual thermal amplitudes are low (normally below $10^{\circ} \mathrm{C}$ ). Summers are fresh and winters are mild, with only a few areas receiving a couple of light frosts per year. Mean annual temperatures range between 14 and $16^{\circ} \mathrm{C}$. Almost every month is wet (there are only two dry months). Precipitation is high throughout the year, reaching its highest levels during autumn and winter. Annual rainfall can vary from $1000 \mathrm{~mm}$ in low-lying coastal areas to $>3000 \mathrm{~mm}$ at higher elevations (Medeiros, 2005; Monteiro, 2005).

\section{SOURCES AND METHODOLOGY}

\subsection{Benedictine diaries (1798-1830)}

In December 1797, the Abbot Primate of the Benedictine Congregation of Portugal, Frei Bernardo da Esperança Teles, established the obligation for each community to appoint a curious and perceptive monk to write the diary of physical, moral, political, and literary 
events, [...] without any apparatus of reflection, with truth, conciseness, and clarity ${ }^{2}$. The expected goal was to facilitate future generations the necessary means to write history without those defects and uncertainties, which naturally result from the lack of true news ${ }^{3}$.

These diaries, called dietários, were conceived to present two types of records, depending on the nature of the monasteries. If they were urban, such was the case of the Benedictine monasteries of Porto, Lisbon, and Coimbra, as well as the mother abbey of Tibães (Braga), they should record what happened on a national and international scale. Indeed, they had access to information through national and foreign newspapers, which would be bought at the expense of the same monasteries and which would be deposited in their respective libraries, after being consulted ${ }^{4}$. The other Benedictine monasteries should record the memories of the events occurred in the city, towns, and villages of the surrounding territory ${ }^{5}$.

The selection of the monk responsible for writing the diaries should follow strict criteria: he will always be chosen by the prelate, with our approval, from the class of those who, by their character or recognised curiosity and application, are deemed to be more worthy of such an important and serious task ${ }^{6}$. In case of equal merit and competence, preference should be given to the most free and resourceful monk able to devote himself to this task with care and assiduous diligence ${ }^{7}$. If the diarist monk happens to be absent for more than four days, another monk should replace him ${ }^{8}$. If his work is carried out with high diligence, the monk is entitled to some benefits ${ }^{9}$. The following instructions prove how rigorous the selection of those who wrote the diary was and how it should be written. However, unfortunately, we do not know the names of the selected monks.

2. Arquivo Distrital de Braga, Monástico-conventual, Beneditinos, Ganfei (Valença), Mosteiro do Salvador, n. ${ }^{\circ} 59$, fs. 1-1v, Dietário e costumeiro. All quotes from "dietários" are translations into English by the author. The original texts are in Portuguese.

3. Arquivo Distrital de Braga, Monástico-conventual, Beneditinos, Ganfei (Valença), Mosteiro do Salvador, n. ${ }^{\circ}$ 59, f. 1 , Dietário e costumeiro.

4. Arquivo Distrital de Braga, Monástico-conventual, Beneditinos, Ganfei (Valença), Mosteiro do Salvador, n. ${ }^{\circ} 59, \mathrm{f} .1 \mathrm{v}$, Dietário e costumeiro.

5. Arquivo Distrital de Braga, Monástico-conventual, Beneditinos, Ganfei (Valença), Mosteiro do Salvador, n. ${ }^{\circ} 59$, f. 1v, Dietário e costumeiro.

6. Arquivo Distrital de Braga, Monástico-conventual, Beneditinos, Ganfei (Valença), Mosteiro do Salvador, n. ${ }^{\circ} 59$, fs. 1-1v, Dietário e costumeiro.

7. Arquivo Distrital de Braga, Monástico-conventual, Beneditinos, Ganfei (Valença), Mosteiro do Salvador, n. ${ }^{\circ} 59, \mathrm{f} .1 \mathrm{v}$, Dietário e costumeiro.

8. Arquivo Distrital de Braga, Monástico-conventual, Beneditinos, Ganfei (Valença), Mosteiro do Salvador, n. ${ }^{\circ}$ 59, f. 2, Dietário e costumeiro.

9. Arquivo Distrital de Braga, Monástico-conventual, Beneditinos, Ganfei (Valença), Mosteiro do Salvador, n. ${ }^{\circ}$ 59, fs. 1v-2, Dietário e costumeiro. 
At the beginning of each month, a copy of the previous month's records would be sent to the Secretary of the Congregation for us to be sure of the execution of what is determined here. Every three months, another copy should be sent to the Chief Chronicler of the Congregation, who will be obliged to make a General Diary arranged in the same order, which would include national and foreign news, after they were selected and verified ${ }^{10}$.

Unfortunately, not all the Benedictine diaries were found. Today, we only know the existence of the diaries of the monasteries of Ganfei (Valença) ${ }^{11}$, Tibães (Braga) ${ }^{12}$, Neiva (Viana do Castelo $^{13}$, Rendufe (Amares) ${ }^{14}$, Pombeiro (Felgueiras) ${ }^{15}$, and Estrela (Lisbon) ${ }^{16}$ (Fig. 1). In the first two cases, we find daily/monthly weather records for several years. In the remaining diaries, the content is mainly about the Napoleonic wars, especially the Peninsular War. In this study, we will focus our analysis on the Ganfei's and Tibães's diaries, both produced in the agricultural region of Entre-Douro-e-Minho, in the northwest of Portugal (Fig. 1).

\subsubsection{Ganfei's diary (1800-30)}

The Benedictine Monastery of Ganfei is located in the border with Galicia, five kilometres from Valença, on the left bank of the Minho river (Fig. 1). Among political, civil, economic, and cultural data, Ganfei's diary includes a weather report entitled "Weather from the first of January from the year 1800 onwards" ${ }^{\prime 17}$. The records are quite short and refer to singular days, as we can see from the following example for January 1800: Day 1. sun and hot wind. Day 2. cloudy. Day 3. rain. Day 4. rain. Day 5. rain and hot wind. Day 6. rain and strong wind. Day 7. cloudy. Day 8. thunder and heavy rain. Day 9. stormy wind and thunder ${ }^{18}$.

10. Arquivo Distrital de Braga, Monástico-conventual, Beneditinos, Ganfei (Valença), Mosteiro do Salvador, n. ${ }^{\circ} 59$, f. 1v, Dietário e costumeiro.

11. The original manuscript diary is kept in the Braga District Archive.

12. The original manuscript diary is kept in the archive of the Monastery of São Bento de Singeverga (Santo Tirso).

13. The original manuscript diary is kept in the Braga District Archive.

14. The original manuscript diary is kept in the parochial archive of S. Tiago de Caldelas (Amares) (DiAs, 1995).

15. Transcribed and edited in CoutinHo (2011).

16. Partly transcribed and edited in SEPÚlveda (1913).

17. Arquivo Distrital de Braga, Monástico-conventual, Beneditinos, Ganfei (Valença), Mosteiro do Salvador, n. ${ }^{\circ}$ 59, f. 3, Dietário e costumeiro.

18. Arquivo Distrital de Braga, Monástico-conventual, Beneditinos, Ganfei (Valença), Mosteiro do 
Weather observations were regularly and carefully noted on a day-to-day basis from the $1^{\text {st }}$ of January 1800 to the $6^{\text {th }}$ of July 1804 -without any interruption-, when suddenly the records were interrupted. For that reason, from this latter date to the $29^{\text {th }}$ of June 1814 , we did not find any climate information. From the $29^{\text {th }}$ of June 1814 to January 1830 there only are individual descriptions on extreme weather events.

\subsubsection{Tibães's diary (1798-1829)}

The diary of the Monastery of São Martinho de Tibães -located on the outskirts of the city of Braga (Fig. 1)-, was started in 1798. The content is divided into four sections, being the second one entitled physical, meteorological, and medical diary ${ }^{19}$, which includes annual and monthly records about local weather and weather-related events.

The first weather record of the Tibães's diary refers to the harsh winter of 1798-99, and the last one dates from the $22^{\text {nd }}$ of February 1829. Between these two dates, the quality and detail of the information varies a lot. Between December 1798 and July 1800, we have monthly descriptions of the local weather, complemented with information from foreign public papers and letters from Lisbon; in February 1800, for example, the monk wrote: In February it rained with the same excess as the previous months; there were a few thunderstorms; and the letters from Lisbon announced that on the 25th, at 7:30 a.m., after a thunderstorm and heavy rain, an earthquake of very short duration was felt in the capital $[\ldots]^{20}$. But, between August 1800 and December 1803, no such information was recorded. From 1804 to 1810 , with the exception of 1809, the writer gave annual descriptions on the meteorological behaviour of the region, as we can see in the following example, for 1805 :

All this year has been fairly regular in heat, cold, and rain. The winter [1804-5] was rainy, but not excessively. Only at the end of August, we felt heat with some intensity. This regularity promised a noticeable abundance of all fruits, especially bread, which was sold for 300 réis [Portuguese currency at the time]. However, in the autumn, there was some unexpected cold, which delayed the crops $[\ldots]^{21}$.

Salvador, n. ${ }^{\circ}$ 59, f. 3, Dietário e costumeiro.

19. Arquivo de Singeverga, Dietário de Tibães.

20. Arquivo de Singeverga, Dietário de Tibães, f. 34.

21. Arquivo de Singeverga, Dietário de Tibães, f. 101. 
For 1809 and from January 1811 to April 1819, this Benedictine diary contains qualitative descriptions of monthly weather; from January to April 1817, for example, their notes read:

The first days [of January] were rainy, but from the $4^{\text {th }}$ it was sunny, until the $18^{\text {th }}$ and the $20^{\text {th }}$ in which there was rain and cold as usual in this season, and from the $21^{\text {st }}$ to the end [of January] there was nice sunshine again. February was all sunny as one would wish in fune. In March all days were sunny, except for a morning, when it rained for about an hour. In April, the same sun, the same dryness, so sterility will certainly be great $[\ldots]^{22}$

Between April 1819 until the $22^{\text {nd }}$ of February 1829, except for individual descriptions on extreme weather events, we only found annual descriptions for the years 1825 and 1828.

Moreover, qualitative descriptions of annual/monthly weather were usually followed by information concerning the growth of crops and the harvests, as we can see from the following example for September and October 1813: September was good and it would have been better if some frosts that burned the maize had not fallen by the end of the month. October was very cold and rainy, which made harvesting difficult and did not let the cereals dry ${ }^{23}$. Such reports are also often -although not always- accompanied by the prices of grain, fruit, and vegetables.

\subsection{Interpretation of Benedictine weather records: Climate indices from documentary sources}

The Benedictine monks used a wide range of terms to describe weather conditions, followed by adjectives that express the magnitude or the intensity of the phenomenon. In Tibães, they also describe the quality and quantity of harvests and crops, in the same way. Based on these terms and adjectives, we developed indices for precipitation, temperature, and agricultural production, converting the qualitative expressions into categories of intensity. The weather records were carefully examined through content analysis in order to build the best possible index. Table 1 shows the original expression in Portuguese -and English- by category ${ }^{24}$.

22. Arquivo de Singeverga, Dietário de Tibães, f. 110.

23. Arquivo de Singeverga, Dietário de Tibães, f. 105.

24. The climate indices are commonly used in Historical Climatology. This method consists in es- 
The daily records precipitation from Ganfei's diary were grouped into four categories: heavy rain, rain, little rain, and no rain. The daily temperature records were grouped into seven categories: very cold, cold, cool, no adjectivisation/mild, warm, hot, and very hot. The index value was assigned to each individual day.

TABLE 1

\section{Precipitation, temperature, and agricultural production indices (categories)}

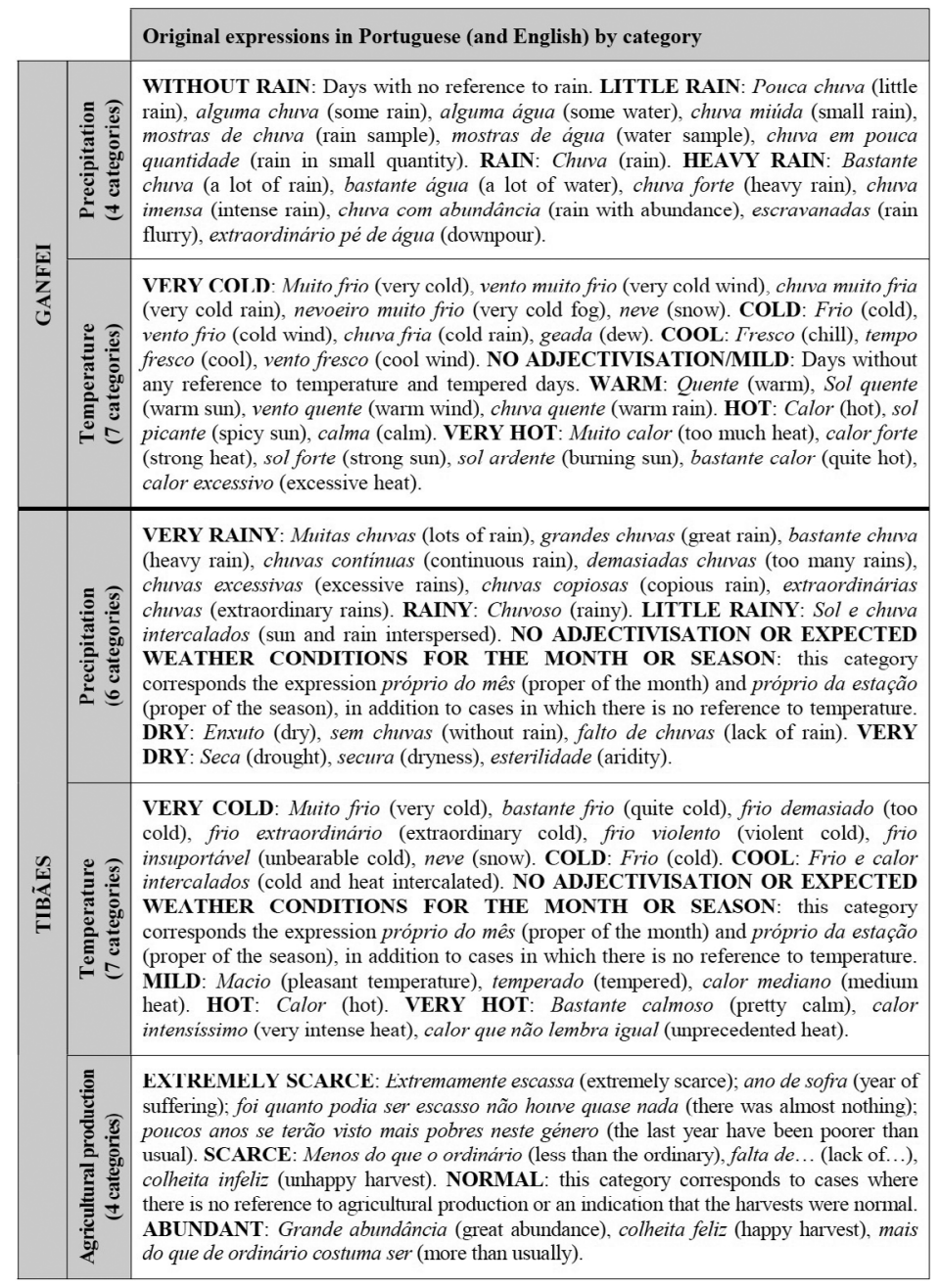

Sources: own elaboration from Arquivo de Singeverga, Dietário de Tibães, and Arquivo Distrital de Braga, Monástico-conventual, Beneditinos, Ganfei (Valença), Mosteiro do Salvador, n. ${ }^{\circ}$ 59, Dietário e costumeiro.

tablishing a graded scaling system to transform documentary evidence in an ordinal system. Different scales of indices have been used for several authors (WHITE, PFISTER \& MAUEKSHAGEN, 2018). 
The monthly records precipitation from Tibães's diary were grouped into six categories: very rainy, rainy, little rainy, no adjectivisation or expected weather conditions for the month or season, dry, and very dry. The monthly temperature records were grouped into seven categories: very cold, cold, cool, no adjectivisation or expected weather conditions for the month or season, mild, hot, and very hot. Finally, the information about agricultural production was grouped into four categories: extremely scarce, scarce, normal, and abundant. The index value was assigned to each individual month.

For a more accurate and reliable analysis, we compared the weather records from Benedictine diaries with those of Pro Pluvia and Pro Serenitate rogations ${ }^{25}$, early available meteorological measurements, and proxy-data. Moreover, in order to investigate more conclusively the connection between crops and weather, the Benedictine records were compared with price series of the three main grain crops grown in the Entre-Douro-eMinho's lands (i.e. maize, rye, and wheat) in five local markets (Caminha, V. Castelo, P. Lima, Tibães, and Porto); and with triennial grain (meado, a mix of maize and rye) tithe series from three Benedictine monasteries of the same region (Ganfei, Tibães, and Santo Tirso) $)^{26}$.

\section{RESULTS}

The winter of 1798-99 was described as one of the most severe in terms of cold and rain that has been experienced in Portugal for many years ${ }^{27}$ (Figs. 4, 5). During this period, frequent and flash floods that caused considerable loss of goods and ruined crops ${ }^{28}$ were observed. The cold and the excessive rains continued during the whole springtime, with small interruptions ${ }^{29}$. In June and July, the weather improved, bringing hope to the farmers $b e-$ cause the crops appeared beautiful allowing for an abundant year. [...] August was cooler

25. Pro Pluvia and Pro Serenitate rogations are public rogations celebrated in order to ask God for rain (Pro Pluvia) or for fair weather (Pro Serenitate). Such ceremonies were performed when crops were threatened by adverse weather conditions and involved the entire community (religious, municipal, and civil agents). This data has been analysed in detail for Spain (e.g. BARRIENDOS, 1997; DoMíNGUEZ CASTRO et al., 2012; FERNÁNDEZ CORTIZO, 2016), and the study is only at the beginning for Portugal (SILVA, 2017, 2019).

26. The technical details behind these series go beyond the scope of this paper, so we refer the interested reader to GodinHo (1955), Oliveira (1973, 1979, 1982), and Silva (1993), which deals with all of the details.

27. Arquivo de Singeverga, Dietário de Tibães, f. 31.

28. Arquivo de Singeverga, Dietário de Tibães, f. 31v.

29. Arquivo de Singeverga, Dietário de Tibães, f. 32v. In Vigo, rogations were celebrated on the $13^{\text {th }}$ of May 1799 to ask for the rain to stop (GONZÁLEZ FERNÁNDEZ, 2000). 
than expected for the season, but the fields and olive groves continued to promise a good year $^{30}$. However, the autumn of 1799 was almost all rainy, which made harvesting difficult. A great quantity of maize and beans were lost, because there weren't fifteen successive days where the conditions were suitable for the harvest to be completed. The grapes had rotted because of the frequent and continuous rains and the ones that resisted turned out to be of poor quality. Fruit harvesting was particularly scarce ${ }^{31}$ (Fig. 6).

A severe food crisis hit the Entre-Douro-e-Minho region in 1799. Tormented by famine and diseases, the population rebelled against the prices of food and speculators, demanding justice and mercy ${ }^{32}$. The Benedictine monasteries of the region were attentive to the serious shortage of food, and came to the aid of the people, distributing alms to help those in need ${ }^{33}$.

The poor harvest of 1799 was aggravated by the winter that followed (Figs. 4, 5). The end of December 1799 was marked by extraordinary cold and heavy snowfalls ${ }^{34}$. The following month was extremely stormy: it rained copiously and without interruption, with strong winds blowing from the south and the west almost continuously and with violence ${ }^{35}$. The bitter winter was fatal for the olives (Fig. 6). For over thirty years there was no memory of such unfortunate harvests of this precious product ${ }^{36}$. The months of February and March 1800 remained very rainy, with the same excess as the previous ones ${ }^{37}$.

In Ganfei, the first two months of 1800 were also quite rainy (Fig. 2). January had 22 days of rain and February $19^{38}$. These two months were the rainiest of the first five years of the 1800s, along with November 1803 and March 1804.

30. Arquivo de Singeverga, Dietário de Tibães, f. 32v.

31. Arquivo de Singeverga, Dietário de Tibães, f. 33.

32. Arquivo de Singeverga, Dietário de Tibães, fs. 52-52v.

33. Arquivo de Singeverga, Dietário de Tibães, fs. $51 \mathrm{v}-52$.

34. Arquivo de Singeverga, Dietário de Tibães, f. 33. On the $21^{\text {st }}$ of December 1799 , the cold brought a white blanket of snow to Barcelona, a very unusual thing in this city (BARRIENDOS, 2005).

35. Arquivo de Singeverga, Dietário de Tibães, f. 33v.

36. Arquivo de Singeverga, Dietário de Tibães, fs. 33-33v.

37. Arquivo de Singeverga, Dietário de Tibães, f. 34.

38. Arquivo Distrital de Braga, Monástico-conventual, Beneditinos, Ganfei (Valença), Mosteiro do Salvador, n. ${ }^{\circ}$ 59, f. 3, Dietário e costumeiro. Impressive numbers if we consider that during the period 1926-41, in Caminha (a neighbouring town), January presented, on average, 15 days of rain, and February had, on average, 12 days of rain (FERREIRA, 1942b). 
The extraordinary rains in the autumn of 1799 and in the winter of 1799-1800 caused serious damages in other parts of the kingdom, wrecking houses and flooding the fields ${ }^{39}$. From January to March 1800, public rogations were celebrated in Monção ${ }^{40}$, Porto ${ }^{41}$, Coimbra (Silva \& Figueiredo, 2018), and Lisbon ${ }^{42}$ to ask God to stop the rain.

On the $29^{\text {th }}$ of June 1800 there was a heavy thunderstorm in Tibães and surrounding areas, which caused some casualties -some even fatal-, after a lightning strike, as well as significant damage to property ${ }^{43}$.

\section{FIGURE 2}

\section{Precipitation level in Ganfei, 1800-04}

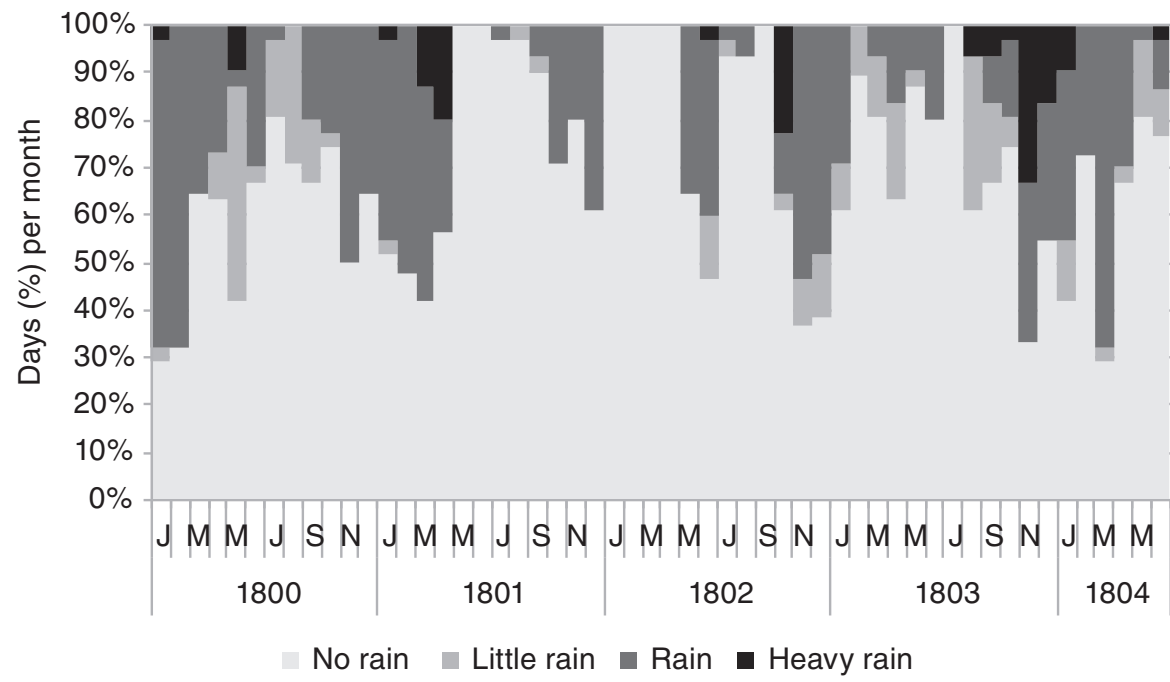

Source: own elaboration from Arquivo Distrital de Braga, Monástico-conventual, Beneditinos, Ganfei (Valença), Mosteiro do Salvador, n. ${ }^{\circ}$ 59, Dietário e costumeiro.

The winter of 1801-02 and the beginning of the following spring were characterised by lack of rain and intense cold. In Ganfei, between January and April 1802, there was not

39. Arquivo de Singeverga, Dietário de Tibães, f. 34.

40. Arquivo Municipal de Monção, Santa Casa da Misericórdia de Monção, 1-A.3.3.4, f. 144, Livro de Acórdãos; Arquivo Municipal de Monção, Santa Casa da Misericórdia de Monção, 1-A.2.3.7, f. 62v, Conta da receita e despesa da Santa Casa da Misericórdia de Monção.

41. Arquivo Episcopal da Diocese do Porto, 85, Indice de Pastoraes e documentos diversos que se acham archivados na camara ecclesiastica da diocese do Porto nos diversos maços com a designação de-Pastoraes e Circulares.

42. Arquivo de Singeverga, Dietário de Tibães, f. 33v.

43. Arquivo de Singeverga, Dietário de Tibães, f. 36. 
FIGURE 3

Thermal regime in Ganfei, 1800-04

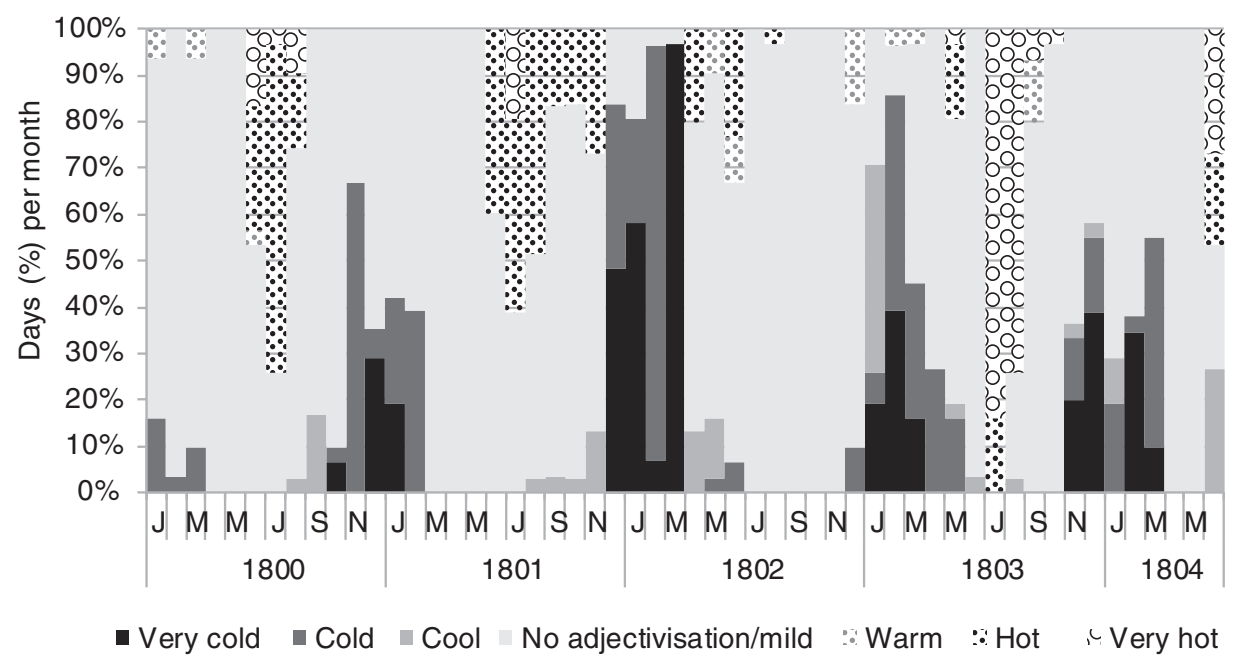

Source: own elaboration from Arquivo Distrital de Braga, Monástico-conventual, Beneditinos, Ganfei (Valença), Mosteiro do Salvador, n. ${ }^{\circ}$ 59, Dietário e costumeiro.

a single rainy day, and in the first quarter of this year almost every day was cold or very cold $^{44}$ (Figs. 2, 3). However, this must have had no serious impact on agriculture, because in May and June it rained abundantly ${ }^{45}$. In Penafiel, prayers were celebrated in a mass of thanksgiving for the gift of rain in this current month of May ${ }^{46}$.

After a winter and a spring with few rains, the summer of 1803 was also dry and hot. In Ganfei, July and August seem to have been the hottest months of the first five-year period of the $1800 \mathrm{~s}$, with the highest number of very hot days (more than $75 \%)^{47}$ (Figs. 2, 3). In Braga, the municipal authorities complained about the summer of 1803 because it

44. Arquivo Distrital de Braga, Monástico-conventual, Beneditinos, Ganfei (Valença), Mosteiro do Salvador, n. ${ }^{\circ} 59$, fs. $4-4 v$, Dietário e costumeiro.

45. Arquivo Distrital de Braga, Monástico-conventual, Beneditinos, Ganfei (Valença), Mosteiro do Salvador, n. ${ }^{\circ} 59$, f. $4 \mathrm{v}$, Dietário e costumeiro.

46. Arquivo Municipal de Penafiel, Santa Casa da Misericórdia de Penafiel, PT/AMPNF/SCMP/ C/B/011/lv.05, f. 160v, Despesa. In Vigo, public prayers were made in July 1802, because the heat for the preservation of the hanging fruits is missing, that if continues like this the corn will perish (GONZÁLEZ FERNÁNDEZ, 2000).

47. Arquivo Distrital de Braga, Monástico-conventual, Beneditinos, Ganfei (Valença), Mosteiro do Salvador, n. ${ }^{\circ} 59$, fs. 5v-6, Dietário e costumeiro. 
FIGURE 4

Precipitation level in Tibães, 1799-1819
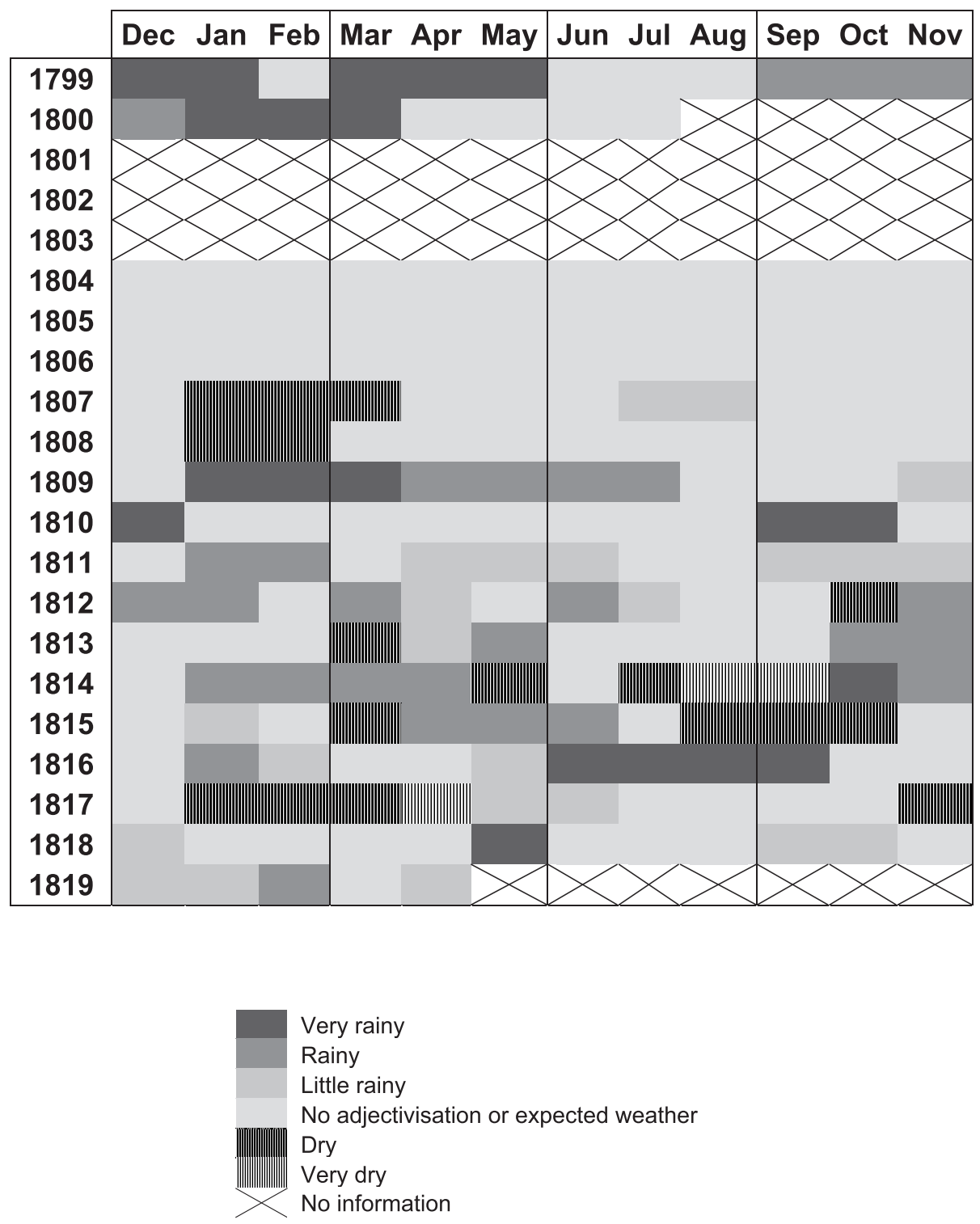

Source: own elaboration from Arquivo de Singeverga, Dietário de Tibães. 


\section{FIGURE 5}

Thermal regime in Tibães, 1799-1819

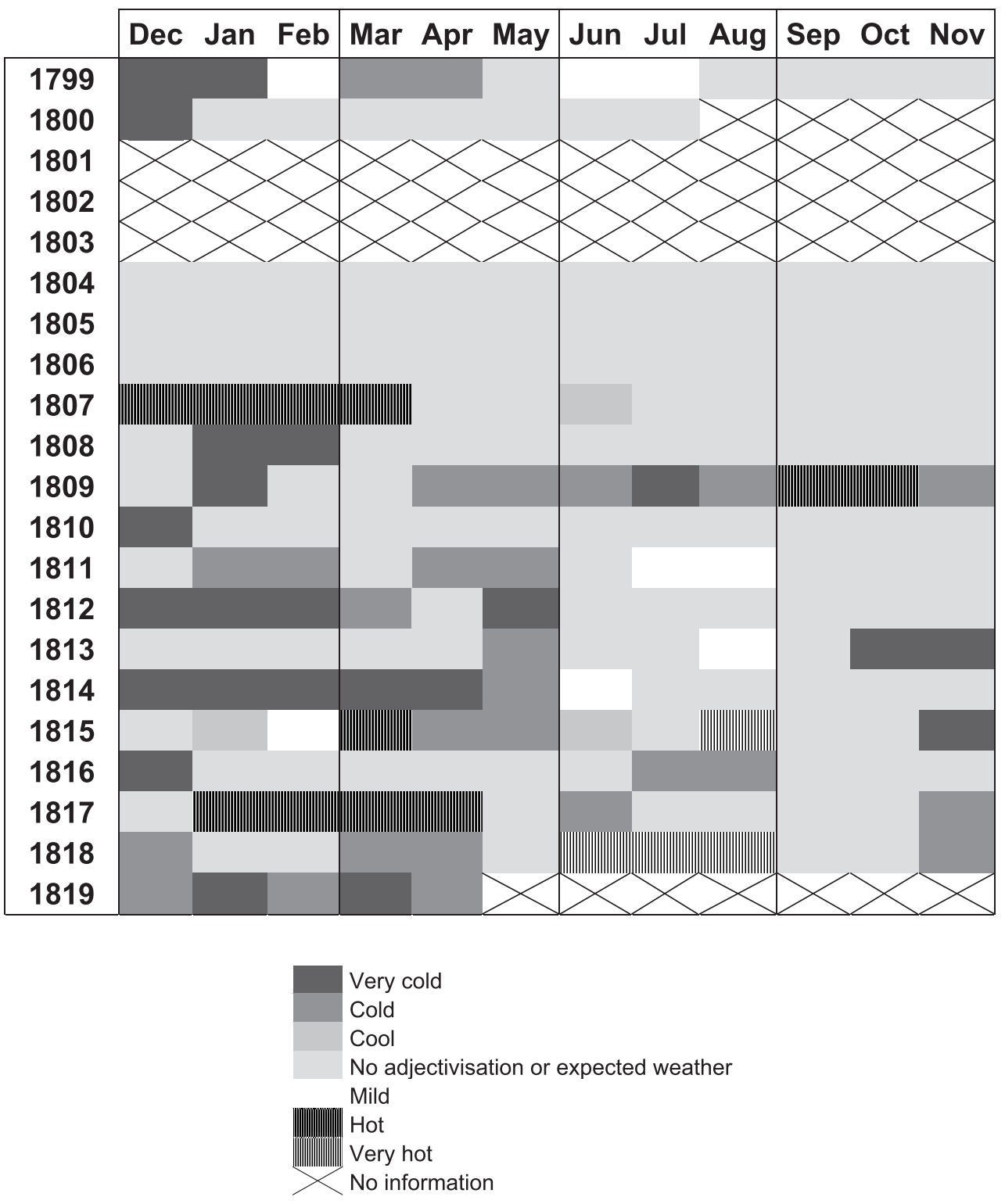

Source: own elaboration from Arquivo de Singeverga, Dietário de Tibães. 
FIGURE 6

Agricultural production in Tibães, 1799-1819
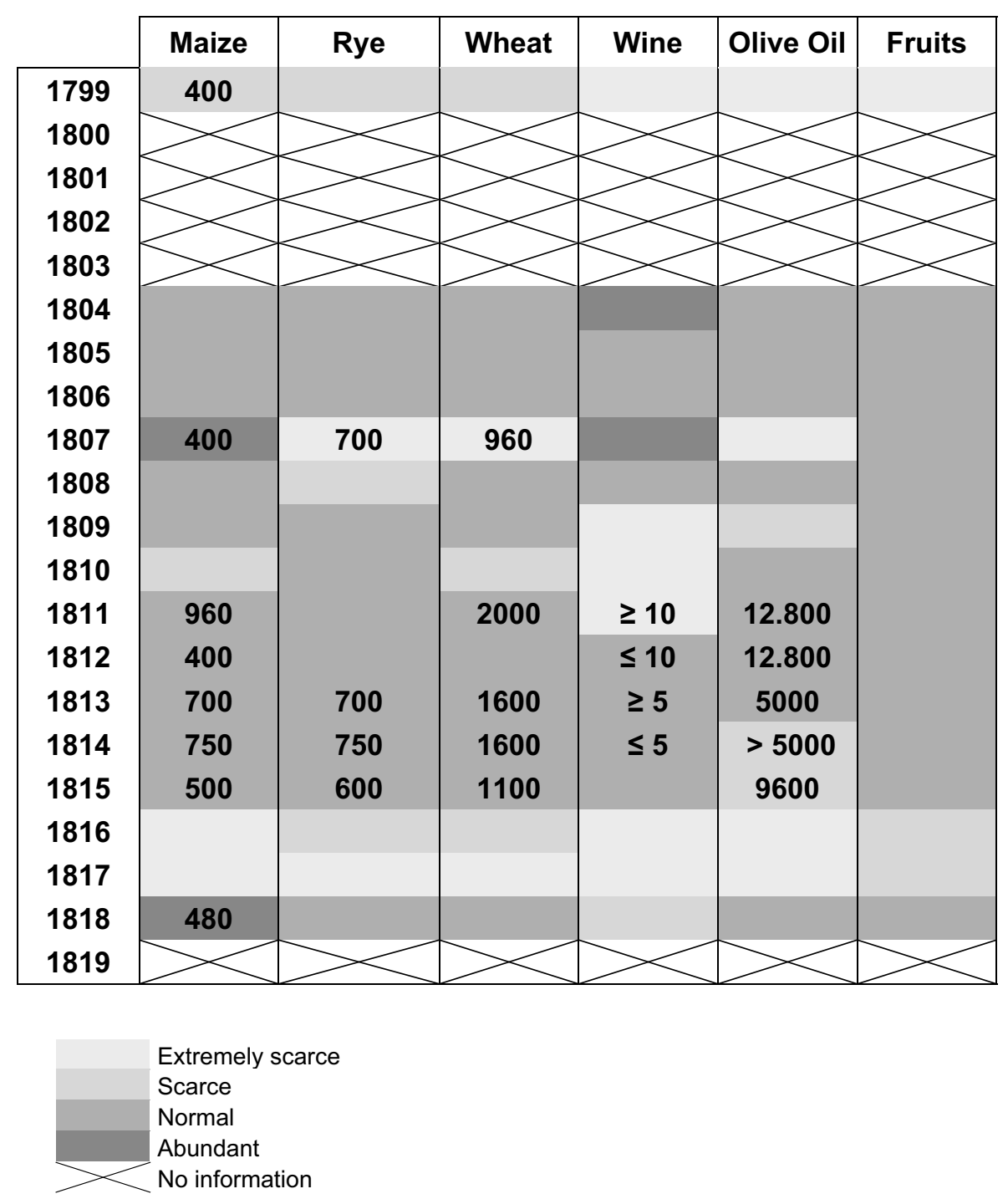

Note: inside the boxes, we put -whenever this information is available- the estimated annual average price of maize (réis/bushel), rye (réis/bushel), wheat (réis/bushel), wine (moedas/pint), and olive oil (réis/almude), provided by the diarist monk of Tibães.

Source: own elaboration from Arquivo de Singeverga, Dietário de Tibães. 
was very hot and the streams had dried $u p^{48}$. In Penafiel and Caminha, public prayers were held in July ${ }^{49}$.

As far weather conditions are concerned, the year 1804 was fairly regular (Figs. 4, 5); there was a great abundance of food supplies and a tendency for the prices to drop. According the diarist monk of Tibães the price of bread went from 720 réis to 400 réis and less. That year, wine was so abundant that there were not enough vessels to collect it in the Monastery of S. Martinho de Tibães ${ }^{50}$ (Fig. 6).

The year 1805 remained fairly regular in heat, cold, and rain (Figs. 4, 5). The winter (1804-05) was rainy but not excessively. The heat was felt with some intensity only at the end of August. This regularity promised a rare abundance of all fruits, especially bread, which was sold for 300 réis. However, in the autumn, some cold came unexpectedly, which delayed the crops, and, in the end, there was not even half of the abundance one expected. Even so, this year's harvests were very good, so that there will not be the same scarcity that existed in previous years ${ }^{51}$ (Fig. 6).

The following year, 1806, was very similar to the previous one, regarding temperature and the abundance of crops (Figs. 4, 6). The seasons were regular, and the prices of food were nearly always the average price, for this region ${ }^{52}$. Even so, in Braga, the autumn rains seemed to be an inconvenience for the population that, on the $26^{\text {th }}$ of October, public prayers were made for the conclusion of the harvest, which was stopped ${ }^{53}$.

The winter of 1806-07 was characterised by a lack of rain and abnormally high temperatures (Figs. 4, 5). Until April it did not rain, and only in this month the cold was felt with some intensity. For this reason, the sowing was delayed, and a bad agricultural year was predicted. June had very hot and very cold days ${ }^{54}$. Fortunately, July and August were warm with an admirable alternation between sun and rain, which was very good for some agricultural crops ${ }^{55}$. In the end, the harvest of 1807 was quite abundant

48. Arquivo Municipal de Braga, Câmara Municipal de Braga, n. ${ }^{\circ}$ 1925, Livro dos Acórdãos.

49. Arquivo Municipal de Penafiel, Santa Casa da Misericórdia de Penafiel, PT/AMPNF/SCMP/C/B/011/lv.05, f. 201v, Despesa; Arquivo Distrital de Viana do Castelo, Misericórdia de Caminha, 7.35.1.24, f. 137, Livros de receita e despesa.

50. Arquivo de Singeverga, Dietário de Tibães, f. 100.

51. Arquivo de Singeverga, Dietário de Tibães, f. 101.

52. Arquivo de Singeverga, Dietário de Tibães, f. 101v.

53. Arquivo Distrital de Braga, Santa Casa da Misericórdia de Braga, 23, f. 10, $21 .{ }^{\circ}$ Livro dos Termos.

54. Arquivo de Singeverga, Dietário de Tibães, f. 101v. 
in maize and in wine ${ }^{56}$ (Fig. 6). The monks of Tibães sold a lot of maize at 400 réis, and its price would have been lower if there was no shortage of rye, which was sold at 700 réis and the wheat at 960 réis. The olive oil production was scanty due to the olive rust disease that has been damaging, for so many years, the olive groves and making it such an expensive product ${ }^{57}$.

January and February 1808 were entirely dry and very cold. In March it rained a little bit, benefiting the rye, which in some regions didn't even bloom, due to very dry weather $^{58}$ (Figs. 4, 5, 6).

Probably as a result of a very large explosive volcanic eruption (The unknown eruption of 1808-1809, see Guevara-Murua et al., 2014), the weather in 1809 can be summed up as very cold and wet, including the summer months (Figs. 4, 5). January was too cold and there were too many rains, which continued through February and March ${ }^{59}$. April and May were also rainy and extraordinarily cold ${ }^{60}$. June continued colder than hot ${ }^{61}$. July was not only rainy, but even snowy, and, therefore, very cold ${ }^{62}$. August was hot, although much less than the usual for the season ${ }^{63}$. Fortunately, at the end of the summer, and much of the autumn, there was good weather, which allowed the fruit to ripen and be harvested. Thus, the year, in terms of agricultural production, was moderate in all products, except for wine and olive oil (very scarce) (Fig. 6) ${ }^{64}$.

The year 1810 was very similar to the previous one, because it was practically all rainy ${ }^{65}$. With regard to agricultural production, the year was prosperous in wheat and maize. How-

55. Arquivo de Singeverga, Dietário de Tibães, f. 102. In Central Europe, the summer of 1807 was quite hot and dry. In Germany, for example, at the beginning of August, the grapes were almost ripe, due to the unbearable heat (Arquivo de Singeverga, Dietário de Tibães, f. 102v).

56. Arquivo de Singeverga, Dietário de Tibães, f. 102.

57. Arquivo de Singeverga, Dietário de Tibães, f. 102.

58. Arquivo de Singeverga, Dietário de Tibães, f. 102v.

59. Arquivo de Singeverga, Dietário de Tibães, f. 102v.

60. Arquivo de Singeverga, Dietário de Tibães, f. 103.

61. Arquivo de Singeverga, Dietário de Tibães, f. 103.

62. Arquivo de Singeverga, Dietário de Tibães, f. 103.

63. Arquivo de Singeverga, Dietário de Tibães, f. 103.

64. Arquivo de Singeverga, Dietário de Tibães, f. 103. These climatic anomalies (high precipitation and consistently low temperatures, even in the summer months), in 1809, have been also described by FERNÁNDEZ FÉRNANDEZ et al. (2015) and FERNÁNDEZ FÉRNANDEZ et al. (2017) for Zafra (southwest of Spain). These authors also acknowledge the influence of a powerful volcanic eruption (VEI=6) in the weather, in this region.

65. Arquivo de Singeverga, Dietário de Tibães, f. 103v. 
ever, the long winters made their harvesting difficult, and large quantities were lost in the fields ${ }^{66}$. To make matters worse, a frost in late April burned the whole vineyard, so few years have been as poor as this one $e^{67}$ (Figs. 4, 5, 6). The shortage of crops in 1810, combined with the entrance of the French army in Portugal, lead to a mortality increase and a sharp rise of prices throughout the region, which lasted for some years ${ }^{68}$.

From a meteorological point of view, the year 1811 seems to have been fairly regular (Figs. 4, 5). January and February were rainy and cold, while March was calm and the temperatures were normal for the month ${ }^{69}$. April, May, and June were cold (with snowfall in April) and rainy ${ }^{70}$. The summer was mild and there was practically no rain at all ${ }^{71}$. During the autumn months, the weather alternated between rainy and dry days, which was very good for the harvest ${ }^{72}$. December was rainy and superabundant in frosts and unbearable cold ${ }^{73}$. Despite this apparent climatic regularity, the wine harvest was lower than normal (probably due to the cold spring months, during the sensitive flowering stages). For this reason, the price of wine has risen to an unprecedented value. Maize was sold at 960 réis and wheat at 2000 réis $^{74}$ (Fig. 6).

The year 1812 was also normal regarding the meteorological behaviour of the seasons (Figs. 4, 5). The first quarter was rainy and very cold. April started with clear skies and from the $10^{\text {th }}$ it had rainy and dry days ${ }^{75}$. May was very cold. June was rainier than hot ${ }^{76}$. In July, the first days were rainy, but on the $10^{\text {th }}$ the sun came up, and the rest of the month was sunny. August, September, and October were very favourable months for the development of agricultural crops and for harvesting. From the $12^{\text {th }}$ of November, it rained always. December was normal for the season ${ }^{77}$. The results of harvests were better than in previous years (Fig. 6). However, still as a consequence of the invasion of the French army, the prices were slightly lower, if we exclude the maize, which was much lower (400 réis); the

66. Arquivo de Singeverga, Dietário de Tibães, f. 103v.

67. Arquivo de Singeverga, Dietário de Tibães, f. 103v.

68. Arquivo de Singeverga, Dietário de Tibães, f. 103v. Cf. DAvid (1992); Amorim (1987); OliveIRA (1996).

69. Arquivo de Singeverga, Dietário de Tibães, f. 103v.

70. Arquivo de Singeverga, Dietário de Tibães, fs. 103v-104.

71. Arquivo de Singeverga, Dietário de Tibães, f. 104.

72. Arquivo de Singeverga, Dietário de Tibães, f. 104.

73. Arquivo de Singeverga, Dietário de Tibães, f. 104.

74. Arquivo de Singeverga, Dietário de Tibães, f. 104.

75. Arquivo de Singeverga, Dietário de Tibães, f. 104v.

76. Arquivo de Singeverga, Dietário de Tibães, f. 104v.

77. Arquivo de Singeverga, Dietário de Tibães, f. 104v. 
wine also went down, but not so much; and the olive oil maintained the same price (12.800 réis/almude) ${ }^{78}$.

The weather throughout 1813 seems to have not registered serious anomalies (Figs. $4,5)$. In the first quarter, temperatures were normal for the season. From mid-March to mid-April it did not rain, but from then through May it was cold and also rainy (all the rain was necessary, because the rye and the wheat were already in a state of underdevelopment due to water shortage $)^{79}$. June and July were normal, except for the $19^{\text {th }}, 20^{\text {th }}$, and $21^{\text {st }}$ of the latter, when it rained so hard that it seemed like the heart of winter ${ }^{80}$. August was mild, and September good, although at the end of last-mentioned month the frosts burned some maize ${ }^{81}$. The last quarter was very cold (with snowfall) and rainy, which made it difficult to dry the grains and for harvesting ${ }^{82}$. Maize and rye were sold at 700 réis, and wheat at 1600 réis, while the price of wine and olive oil has fallen a $\operatorname{lot}^{83}$ (Fig. 6).

After an extremely cold winter and spring (with regular snowfall), the summer and early autumn of 1814 were characterised by a great lack of rain $^{84}$ (Figs. 4, 5). Between July and September, it only rained one day ${ }^{85}$. But from October, it began to rain in abundance $^{86}$. Despite the drought, the prices remained stable, except for the price of olive oil, which is expected to go up a lot because the olive rust disease is still going on ${ }^{87}$ (Fig. 6). In August, public prayers were held in Porto ${ }^{88}$ and in Braga ${ }^{89}$ to ask God for rain ${ }^{90}$.

78. Arquivo de Singeverga, Dietário de Tibães, fs. 104v-105.

79. Arquivo de Singeverga, Dietário de Tibães, f. 105.

80. Arquivo de Singeverga, Dietário de Tibães, f. 105.

81. Arquivo de Singeverga, Dietário de Tibães, f. 105.

82. Arquivo de Singeverga, Dietário de Tibães, fs. 105-105v.

83. Arquivo de Singeverga, Dietário de Tibães, f. 105v.

84. Arquivo de Singeverga, Dietário de Tibães, fs. 105v-106.

85. Arquivo de Singeverga, Dietário de Tibães, fs. 106-107.

86. Arquivo de Singeverga, Dietário de Tibães, f. 107.

87. Arquivo de Singeverga, Dietário de Tibães, f. 107.

88. Arquivo Episcopal do Porto, 85, Indice de Pastoraes e documentos diversos que se acham archivados na camara ecclesiastica da diocese do Porto nos diversos maços com a designação de-Pastoraes e Circulares.

89. Arquivo Distrital de Braga, Santa Casa da Misericórdia de Braga, 23, fs. 235-236v, $21 .^{\circ}$ Livro dos Termos; Arquivo Distrital de Braga, Arquivo do Cabido, f. 159, Tomo 15-Livro das Cartas-Avisos da Secretaria de Estado dos Negócios do Reino e vários outros documentos, 1813.

90. In the same year, but in the spring, prayers Pro Pluvia were organised in some localities in the East of Spain (Domínguez CASTRO et al., 2012). 
The winter of 1814-15 registered temperatures above normal. Despite January being cold, February was more tempered than usual, and March was hot ${ }^{91}$ (Figs. 4, 5). In Penafiel, doctor António de Almeida was also surprised by the benignity of the temperature in the first months of $1815^{92}$. Spring was rainy and cold, but with no negative impact on crops and vineyards, since these were admirably grown in the end of June, thanks to the amenity of the previous winter ${ }^{93}$. The summer and early autumn were seasons with very little rainfall, so harvests were the best they could be, not only in bread, but also in wine ${ }^{94}$. In Porto, Pro Pluvia rogations were held in early September $1815^{95}$. The last two months of the year had particularly cold temperatures, with many dry frosts ${ }^{96}$. At the end of the year, the production balance was positive: this year was not rich; but it has exceeded the previous ones in everything, and, therefore, the prices of food supplies were good ${ }^{97}$ (Fig. 6).

The year 1816 was marked by severe climate abnormalities across the Entre-Douroe-Minho region, most likely caused by the eruption of Mount Tambora, in August 1815 (Oppenheimer, 2003; Gertisser \& Self, 2015) (Figs. 4, 5). The winter of 1815-16 and the following spring appear to have been relatively normal, with only a few windy days in March and April ${ }^{98}$. In the spring and early summer, the fields showed signs that the year would be abundant in all products ${ }^{99}$. However, the summer ended up being plagued by continuous and abundant rains, and presented abnormally low temperatures for this season, ruining farmers' expectations ${ }^{100}$. In Braga, the grape harvest lasted until the $19^{\text {th }}$ of November because, due to the lack of warmth and very cold days, the grapes did not ripen ${ }^{101}$. Tadim, a 78-year-old priest and lawyer from Braga, said that he had never seen such rain and cold [in July 1816], even in the cold winter months, which surprised the older

91. Arquivo de Singeverga, Dietário de Tibães, fs. 107-107v.

92. Biblioteca Pública Municipal do Porto, Manuscritos, ms. 1761[2], fs. 45, 52, Observações meteorológico-médicas de Penafiel.

93. Arquivo de Singeverga, Dietário de Tibães, f. 107v.

94. Arquivo de Singeverga, Dietário de Tibães, fs. 107v-108.

95. Arquivo Episcopal do Porto, 85, Indice de Pastoraes e documentos diversos que se acham archivados na camara ecclesiastica da diocese do Porto nos diversos maços com a designação de-Pastoraes e Circulares. In the same year, public prayers were held in several Spanish locations to request for rain, which suggests that the drought also affected other parts of Iberia (DOMíNGUEZ-CASTRO et al., 2012).

96. Arquivo de Singeverga, Dietário de Tibães, f. 108.

97. Arquivo de Singeverga, Dietário de Tibães, f. 108.

98. Arquivo de Singeverga, Dietário de Tibães, fs. 108-109.

99. Arquivo de Singeverga, Dietário de Tibães, f. 109.

100. Arquivo de Singeverga, Dietário de Tibães, f. 109.

101. Arquivo Distrital de Braga, Manuscritos do Fundo Geral, Diário Bracarense das Épocas, Fastos, e Annaes mais remarcáveis, e successos dignos de mençam, que succederam em Braga, Lisboa, e mais partes de Portugal, e Cortes da Europa, ms. 1055, f. 418. 
people ${ }^{102}$. Also, the diarist monk of Ganfei left his testimony on the irregularity of the weather, in the summer of 1816, summarising it in this manner: rain and cold during the whole month of fuly and part of August ${ }^{103}$. The climatic anomalies resulting from the eruption of Mount Tambora were felt in other places of Portugal, the Iberian Peninsula, and Europe (Trigo et al., 2008; Domínguez Castro et al., 2012; Fernández Fernández et al., 2014; Le Roy Ladurie, 2017 and references therein) ${ }^{104}$. At the end of the year, the results of the harvest were absolutely heart-breaking: the maize was extremely scarce, the wine did not mature, and there was also very little olive oil, not only because of the olive rust disease, but also because of its bad development ${ }^{105}$ (Fig. 6). In Penafiel, the lack of heat and unusual high nebulosity, during the summer of 1816 , also severely affected the quality of olive production ${ }^{106}$.

Both the winter of 1816-17 and the beginning of the following spring were dry and hot (Figs. 4, 5). In Tibães, the months of January, February, March, and April 1817 were all sunny and even hot as one would wish in fune ${ }^{107}$. It started raining in May and it continued until the end of June ${ }^{108}$. To make matters worse, a major storm at the end of August caused a great deal of damage in the fields. The remaining months of the year showed no significant climatic anomalies ${ }^{109}$. In Ganfei, we have information that in January, February, and March 1817 there was sun and even unbearable heat ${ }^{110}$. Throughout April 1817 Pro Pluvia prayers were made in several Portuguese localities, namely in Caminha $^{111}$, Braga ${ }^{12}$, Porto ${ }^{113}$, Penafiel ${ }^{14}$, Ovar (Lamy, 1977: 140), and Trás-os-Montes

102. Arquivo Distrital de Braga, Manuscritos do Fundo Geral, ms. 1055, f. 596, Diário Bracarense das Épocas, Fastos, e Annaes mais remarcáveis, e successos dignos de mençam, que succederam em Braga, Lisboa, e mais partes de Portugal, e Cortes da Europa.

103. Arquivo Distrital de Braga, Monástico-conventual, Beneditinos, Ganfei (Valença), Mosteiro do Salvador, n. ${ }^{\circ}$ 59, f. 7, Dietário e costumeiro.

104. In Vigo, public prayers were held on the $5^{\text {th }}$ of August 1816 (GonZÁlez FERNÁNDEZ, 2000).

105. Arquivo de Singeverga, Dietário de Tibães, f. 109v.

106. Biblioteca Pública Municipal do Porto, Manuscritos, ms. 1761 [2], fs. 109-115, Observações meteorológico-médicas de Penafiel.

107. Arquivo de Singeverga, Dietário de Tibães, f. 110.

108. In Lisbon, May 1817 was unusually rainy (TRIGO et al., 2008).

109. Arquivo de Singeverga, Dietário de Tibães, f. $110 \mathrm{v}$.

110. Arquivo Distrital de Braga, Monástico-conventual, Beneditinos, Ganfei (Valença), Mosteiro do Salvador, n. ${ }^{\circ} 59$, f. $7 \mathrm{v}$, Dietário e costumeiro.

111. Arquivo Municipal de Caminha, Irmandade da Ordem Terceira de S. Francisco, 1.2.2.21, fs. 5959v, Actas das Sessões.

112. Arquivo Distrital de Braga, Arquivo do Cabido, f. 175, Tomo 15-Livro das Cartas-Avisos da Secretaria de Estado dos Negócios do Reino e vários outros documentos, 1813; Arquivo Distrital de Braga, Santa Casa da Misericórdia de Braga, 24, fs. 7-7v, 22. ${ }^{\circ}$ Livro dos Termos. 
(Alves \& Pereira, 2000: 521). In Penafiel, according to the instrumental observations of António de Almeida, the period between January and April 1817, there were high temperatures for the season, which contributed to the unusual phenomenon of the appearance of ripe olives in April 1817. In addition, it only rained in 18 days ${ }^{115}$. The dryness and the high average temperatures for winter/spring, in 1817, were felt in practically all parts of the Iberian Peninsula (Barriendos, 2005; Trigo et al., 2008; Domínguez Castro et al., 2012; Fernández Fernández et al., 2014; Le Roy Ladurie, 2017) ${ }^{116}$. Up to the end of 1817, we also have the information of intense cold, as it had never happened before, in Ganfei, in the last days of December. The water froze [...] inside the houses ${ }^{117}$. If the previous year had already been scarce, the year 1817 was very poor: olive oil, none; wine, very little; bread, even less [Fig. 6]. Farmers who, in other years, had bread for most of the year, this year they have not; famine is certain and wide-ranging ${ }^{118}$.

The abundant rains of May 1818 delayed the sowing of maize in Tibães ${ }^{119}$ (Figs. 4, 5). In the same month, public prayers were celebrated in Penafiel ${ }^{120}$ and in Braga ${ }^{121}$ to ask God for more favourable weather conditions. From the $20^{\text {th }}$ of June, the heat intensified considerably and remained so throughout the summer ${ }^{122}$. At the end of July and early August, prayers were held in Penafiel ${ }^{123}$, Guimarães (Braga, 1993), and Coimbra (Silva \& Figueiredo, 2018) to ask God for rain. In Lisbon, according to instrumental observations by the military engineer Marino M. Franzini, temperatures in June, July, and August 1818 were particularly high (Trigo et al., 2008) ${ }^{124}$. In Penafiel, the absolute max-

113. Arquivo Episcopal do Porto, 85, Indice de Pastoraes e documentos diversos que se acham archivados na camara ecclesiastica da diocese do Porto nos diversos maços com a designação de-Pastoraes e Circulares; Biblioteca Pública Municipal do Porto, Manuscritos, M-VR-77, f. 33, Lbo... de cousas curiosas.

114. Biblioteca Pública Municipal do Porto, Manuscritos, ms. 1980, Memórias de Penafiel.

115. Biblioteca Pública Municipal do Porto, Manuscritos, ms. 1761 [2], fs. 109-115, Observações meteorológico-médicas de Penafiel. During the period 1913-41, between January and April, it rained, on average, 55 days in Penafiel (FERREIRA, 1942b).

116. In Vigo, Pro Pluvia prayers were held on the 14 of April 1817 (GonzÁlez FerNández, 2000).

117. Arquivo Distrital de Braga, Monástico-conventual, Beneditinos, Ganfei (Valença), Mosteiro do Salvador, n. ${ }^{\circ} 59$, f. $7 \mathrm{v}$, Dietário e costumeiro.

118. Arquivo de Singeverga, Dietário de Tibães, f. 110v.

119. Arquivo de Singeverga, Dietário de Tibães, f. 111.

120. Biblioteca Pública Municipal do Porto, Manuscritos, ms. 1980, Memórias de Penafiel.

121. Arquivo Distrital de Braga, Santa Casa da Misericórdia de Braga, 24, f. 31, 22. ${ }^{\circ}$ Livro dos Termos.

122. Arquivo de Singeverga, Dietário de Tibães, f. 111.

123. Biblioteca Pública Municipal do Porto, Manuscritos, ms. 1980, Memórias de Penafiel.

124. The year 1818 was also quite dry in eastern and southern Spain, especially in spring and autumn (Domínguez CaStro et al., 2012). 
imum temperature in June $\left(35.5^{\circ} \mathrm{C}\right)$, July $\left(38.3^{\circ} \mathrm{C}\right)$, and August $\left(36.1^{\circ} \mathrm{C}\right)$ reached record levels in a series of observations by doctor António de Almeida ${ }^{125}$. Despite the abnormally high summer temperatures and the rainy autumn, the crops, in this year, were quite generous: there was a great abundance of maize (sold at 400-480 réis); the wine was less than in ordinary years [...] but it is well-bred; the olive oil was abundant ${ }^{126}$ (Fig. 6).

The winter of 1818-19 was quite cold, accompanied by snowfall not only in the higher regions, but also in the lower ones ${ }^{127}$ (Fig. 5). In Penafiel, December 1818 and January 1819 recorded an absolute minimum temperature of $2.7^{\circ} \mathrm{C}^{128}$.

From April 1819 onwards, Benedictine diaries do not allow, as we have already explained, a systematic reading of the evolution of the weather conditions. Since this year, up to 1830 , we only found annual descriptions -quite succinct- for the period between 1825 and 1828, while in the other years, there are only isolated descriptions of hydrometeorological extremes.

In January 1821 , following heavy rains from the $4^{\text {th }}$ to the $11^{\text {th }}$ day, the Minho river grew considerably, forming an extraordinary flood, that older people could not remember anything of a bigger dimension or anything like $i t^{129}$. The stream of the river destroyed all the agricultural fields on its banks ${ }^{130}$. The extraordinary rains also caused floods in other Portuguese rivers, namely in the river Douro ${ }^{131}$, Sousa ${ }^{132}$, Ave $^{133}$, Mondego $^{134}$, and Tagus ${ }^{135}$.

125. Biblioteca Pública Municipal do Porto, Manuscritos, ms. 1761 [2], fs. 166-171, Observações meteorológico-médicas de Penafiel.

126. Arquivo de Singeverga, Dietário de Tibães, f. $111 \mathrm{v}$.

127. Arquivo de Singeverga, Dietário de Tibães, f. 112.

128. Biblioteca Pública Municipal do Porto, Manuscritos, ms. 1761 [2], fs. 185-189, Observações meteorológico-médicas de Penafiel.

129. Arquivo Distrital de Braga, Monástico-conventual, Beneditinos, Ganfei (Valença), Mosteiro do Salvador, n. ${ }^{\circ}$ 59, f. 16, Dietário e costumeiro.

130. Arquivo Distrital de Braga, Monástico-conventual, Beneditinos, Ganfei (Valença), Mosteiro do Salvador, n. ${ }^{\circ}$ 59, f. 16, Dietário e costumeiro.

131. Arquivo Histórico Municipal do Porto, A-PUB/1191, f. 244, Suplemento às próprias; Correio do Porto, n. ${ }^{\circ} 11,12^{\text {th }}$ January $1821 ; \mathrm{n} .{ }^{\circ} 13,15^{\text {th }}$ January $1821 ; \mathrm{n} .{ }^{\circ} 15,17^{\text {th }}$ January $1821 ;$ Diário $d o$ Governo, n. ${ }^{\circ} 19,22^{\text {nd }}$ January $1821 ; \mathrm{n} .{ }^{\circ} 20,23^{\text {rd }}$ January $1821 ; \mathrm{n} .{ }^{\circ} 23,26^{\text {th }}$ January $1821 ;$ Periódico $d o s$ Pobres no Porto,.$^{\circ}$ 43, $20^{\text {th }}$ February 1843; O Correio Português, n. ${ }^{\circ}$ 360, $25^{\text {th }}$ February 1843; Gazeta Médica do Porto, n. ${ }^{\circ} 17,20^{\text {th }}$ March 1843.

132. Biblioteca Pública Municipal do Porto, Manuscritos, ms. 1980, Memórias de Penafiel.

133. Arquivo Distrital do Porto, Convento de Santa Clara-Vila do Conde, PT/ADPRT/MON/CVSCVCD/0155, fs. 79-79v, Memórias; Arquivo Municipal de Vila do Conde, Câmara Municipal, 973, f. 14, Livro da receita e despesa do concelho.

134. Diário do Governo, n. ${ }^{\circ} 278,24^{\text {th }}$ November 1852. 
The summer and early autumn of 1821 appear to have been unusually dry. Until the $11^{\text {th }}$ of November, it never rained through an entire day or an entire night ${ }^{136}$. On the $11^{\text {th }}$ of November, it rained so hard, that it resembled the waters of the Great Flood ${ }^{137}$. About a month and a half later, on the $28^{\text {th }}$ of December, there was a flood in the Cávado river, which exceeded the previous ones ${ }^{138}$.

The year 1825 was very dry in the Entre-Douro-e-Minho region, especially in the summer, which was extremely $d r y^{139}$. Still, this year was not the least abundant one, because even though it was moderate in cereals, and even scarce in some qualities, as, for example, maize, it was abundant in wine ${ }^{140}$. In Penafiel, according to the observations by António de Almeida, January and February registered only 9 days with rain (a very low value considering all his observations) ${ }^{141}$.

In Ganfei, the whole year 1826 was $d r y^{142}$. In Penafiel, a very rainy winter (1825-26) was followed by a spring and summer that had little precipitation, especially in April and in June ${ }^{143}$. In Lisbon, in April 1826, public prayers requested rain, the lack of which posed particular problems for the agricultural sector ${ }^{144}$.

Dry weather conditions were also observed in the summer of 1827. In Ganfei, this summer was extremely $d r y^{145}$. In Braga, in July, prayers were made to St. Mary Magda-

135. Diário do Governo, n. ${ }^{\circ} 18,20^{\text {th }}$ January 1821.

136. Arquivo Distrital de Braga, Monástico-conventual, Beneditinos, Ganfei (Valença), Mosteiro do Salvador, n. ${ }^{\circ}$ 59, f. 16, Dietário e costumeiro.

137. Arquivo Distrital de Braga, Monástico-conventual, Beneditinos, Ganfei (Valença), Mosteiro do Salvador, n. ${ }^{\circ}$ 59, f. 16, Dietário e costumeiro. In Tui (Spain), on the $12^{\text {th }}$ of November [1821] it rained so extraordinarily in this town and in its suburbs, as in many other parts, that it seemed the whole world was flooded (LosADA, 2008: 169).

138. Arquivo de Singeverga, Dietário de Tibães, f. 112.

139. Arquivo Distrital de Braga, Monástico-conventual, Beneditinos, Ganfei (Valença), Mosteiro do Salvador, n. ${ }^{\circ}$ 59, f. 7v, Dietário e costumeiro; Arquivo de Singeverga, Dietário de Tibães, f. 112v.

140. Arquivo de Singeverga, Dietário de Tibães, f. 112v.

141. Biblioteca Pública Municipal do Porto, Manuscritos, ms. 1980, Memórias de Penafiel. In the period 1913-41, between January and February, it rained on average 27 days in Penafiel (FERREIRA, 1942b). The dry nature of 1825 was not exclusive to the Entre-Douro-e-Minho region. Among the winter of 1824-25 and the spring of 1825, Pro Pluvia rogations were held in several Spanish localities (DOMíNGUEZ CASTRO et al., 2012).

142. Arquivo Distrital de Braga, Monástico-conventual, Beneditinos, Ganfei (Valença), Mosteiro do Salvador, n. ${ }^{\circ} 59$, f. $7 \mathrm{v}$, Dietário e costumeiro.

143. Biblioteca Pública Municipal do Porto, Manuscritos, ms. 1980, Memórias de Penafiel.

144. Correio do Porto, $n .^{\circ} 105,5^{\text {th }}$ May 1826.

145. Arquivo Distrital de Braga, Monástico-conventual, Beneditinos, Ganfei (Valença), Mosteiro do 
lene (a thaumaturgical image, to which people resorted in periods of adverse weather conditions) ${ }^{146}$. In Penafiel, June, July, and August had only seven days of rain, making this summer the driest of the whole series assessed by António de Almeida ${ }^{147}$.

The year 1828 was excessively irregular, because all winter and all summer were rainy, with only a few mild days ${ }^{148}$. In Braga, in August, the population invoked again the image of St. Mary Magdalene ${ }^{149}$. However, in spite of these particular conditions, the agricultural production was abundant overall, except in excessively humid lands ${ }^{150}$.

Between mid-December 1829 and mid-January 1830, the cold in Ganfei was so excessive, that older people can't recall of so much cold. The Minho river froze in its banks $^{151}$. The intense cold in the winter of 1829-30 also affected other regions of Portugal $^{152}$ and Europe (Pfister, 2005) ${ }^{153}$.

\section{DISCUSSION}

\subsection{Benedictine diaries as information sources in climate research}

In an agrarian society, in which the weather was perceived as an economic risk factor, regular and updated meteorological information was seriously taken in account by the Benedictine monastic communities. Owners of large areas of land in northern Portugal, these communities understood the great impact of climatic patterns on crops (both in terms of crop yield and harvest timing) and food prices, keeping daily/monthly non-in-

Salvador, n. ${ }^{\circ} 59$, f. 7v, Dietário e costumeiro.

146. Arquivo Distrital de Braga, Santa Casa da Misericórdia de Braga, 25, fs. 41-41v, 23. ${ }^{\circ}$ Livro dos Termos.

147. Biblioteca Pública Municipal do Porto, Manuscritos, ms. 1980, Memórias de Penafiel. In the period 1913-41, between June and August, it rained on average 14 days in Penafiel (FERREIRA, 1942b).

148. Arquivo de Singeverga, Dietário de Tibães, f.113.

149. Arquivo Distrital de Braga, Santa Casa da Misericórdia de Braga, 25, f. 83v, 23. ${ }^{\circ}$ Livro dos Termos; Arquivo Distrital de Braga, Santa Casa da Misericórdia de Braga, 688, f. 118v, Livro de despesa do mordomo.

150. Arquivo de Singeverga, Dietário de Tibães, fs. 113-113v.

151. Arquivo Distrital de Braga, Monástico-conventual, Beneditinos, Ganfei (Valença), Mosteiro do Salvador, n. ${ }^{\circ} 59$, fs. $16 \mathrm{v}-17$, Dietário e costumeiro.

152. Correio do Porto, n. ${ }^{\circ} 14,16^{\text {th }}$ January $1830 ; n .^{\circ} 38,13^{\text {rd }}$ February $1830 ; n .^{\circ} 40,16^{\text {th }}$ February 1830; Gazeta de Lisboa, n. ${ }^{\circ} 14,16^{\text {th }}$ January 1830.

153. In Barcelona, it snowed in great quantity at Christmas of 1829 and in the $1^{\text {st }}$ of February 1830, something rare in this locality (BARRIENDOS, 2005). 
strumental weather records between the end of the $18^{\text {th }}$ century and the first three decades of the $19^{\text {th }}$ century $(1798-1830)$.

This information is exceptional to study the climate of the northwest of Portugal in the period it covers. Firstly, it allows the reconstruction of basic climatic parameters, especially when cross-checked with other information, such as Pro Pluvia and Pro Serenitate rogations, early instrumental measurements, and different types of proxy-data. Secondly, it can be transformed into continuous temperature, precipitation, and agricultural production indices, converting expressions of a qualitative nature into categories of intensity, which may be applicable to other similar sources (Tab. 1). Thirdly, it allows assessing the possible effects of changes in solar radiation (Dalton Minimum, 1780-1840; see Anet et al., 2014), explosive volcanic eruptions (The Unknown eruption of 1808-1809; see Guevara-Murua et al., 2014; Tambora, 1815; see Oppenheimer, 2003), and the North Atlantic Oscillation (Trigo et al., 2004) on climatic variations in Portugal. And finally, it permits the study of a period marked not only by the lack of continuous instrumental data (Ferreira, 1942a; Alcoforado et al., 2012), but also by the lack of historical data, due to the political and economic instability caused first by the Napoleonic Wars (1803-15), then by the consolidation of Liberalism in Portugal (1820-34), and, finally, by the dissolution of the monasteries (1834).

In fact, these military and political events seem to have affected the quality of the meteorological information compiled in the Benedictine diaries. In Ganfei's diary, the daily weather records that began in January 1800 were suddenly interrupted in July 1804, probably due to the French revolutionary wars and the expansionist dynamics of Napoleonic France, which diverted all of the Benedictine monks' attention to these events. Indeed, several pages of this diary -and other Benedictine diaries- were devoted to the detailed description of Napoleon's military campaigns. In the Tibães's diary, weather observations were regularly and carefully noted on a monthly basis, from December 1798 to July 1800, in 1809 , and from January 1811 to April 1819. In the remaining periods, it only includes shorter descriptions of weather patterns during an entire year and descriptions about extreme weather events, probably due to the laconic nature of the observations, resulting from the great political and social instability in Portugal.

Nevertheless, the Benedictine diaries are one of the most important sources for the history of climate in Portugal for the first third of the $19^{\text {th }}$ century, due to its continuity, homogeneity, and high temporal resolution. One hopes that systematic searches can continue to be made, so more diaries can to come to light and help to fill the gaps in the historical mosaic of the weather in Portugal, both from the point of view of climate reconstruction and the analysis of meteorological extremes. 


\subsection{Climatic variations and extreme weather events}

The final results show a number of outstanding extreme years or anomalies, occurred from 1798 to 1830, in the agricultural region of Entre-Douro-e-Minho, in the northwest of Portugal (Figs. 2, 3, 4, 5, 6).

With regard to thermal anomalies, it was possible to identify a clear predominance of intense cold episodes, particularly in the winter and spring. In Ganfei, between January 1800 and June 1804, there were 135 very cold days (with a maximum in March 1802, 30 days) and only 76 very hot days (with a maximum in July 1803, 26 days). In the same locality, and in the same period, 166 days were cold (with a maximum in February 1802, 25 days) and only 123 days were hot (with a maximum in July 1802, 22 days). In Tibães, between December 1798 and April 1819, except from August 1800 to December 1803, there were 23 very cold months (with a maximum in 1814, 4 months) and only 4 very hot months (with a maximum in 1818, 3 months). In the same locality, and in the same period, 27 months were cold (with a maximum in 1809, 5 months) and only 11 months were hot (with a maximum in 1817, 4 months).

Focusing on the period 1798-1830, one must pay attention to several remarkably cold periods, namely in the winter/spring of 1799 , in the winter/early spring of 1802 , in the winter of 1808 , in the spring/summer of 1809 , in the winter/spring of 1812 , from autumn of 1813 to spring of 1814 , in the last two months of 1815 , in the summer of 1816 , in the winter/spring of 1819, and in the winter of 1829-30. Even so, this period was not free of warm anomalies. The summer of 1803 was interpreted as one of the hottest periods of the first third of the $19^{\text {th }}$ century, followed by the winter/early spring of 1807 , the winter/early spring of 1817, and the summer of 1818 .

As for the precipitation parameter, it showed a strong variability. In Ganfei, there was clearly a prevalence of days with no rain, in all months recorded (1140 days). This may be attributed to an inconsistent registration of precipitation in the daily entries, in which shorter or less abundant precipitation, especially at night, went unnoticed by the diarist. The number of days with heavy rain was 47 (with a maximum in November 1803, 10 days), while with rain was 350 (with a maximum in March 1804, 21 days), and with little rain was 102 (with a maximum in May 1800, 14 days). Only in eight months there was not a single rainy day recorded (May-June 1801, January-April 1802, September 1802, July 1803). The months with the highest number of rainy days (>50\%) were JanuaryFebruary 1800, May 1800, February-March 1801, June 1802, November-December 1802, November 1803, January 1804, and March 1804. In Tibães, the number of wet months was higher than that of the drier ones: 20 months were interpreted as very rainy 
(with a maximum in 1799 and 1816, 4 months each), 28 as rainy (with a maximum in 1814, 5 months), 23 as little rainy (with a maximum in 1811, 6 months), 17 as $d r y$ (with a maximum in 1815 and 1817, 4 months each), and only 3 as very dry (with a maximum in 1814,2 months).

According to both diaries, a markedly consistent drier period occurred in the summers of 1803 and 1814, in the winter/spring of 1817, and again in the summers of 1821 and 1825-27. On the other hand, a markedly consistent wettest period occurred from the late $18^{\text {th }}$ century to the early $19^{\text {th }}$ century, in the winter/spring of 1809 , and in the summer of 1816.

These climatic anomalies could be related to some well know external climate forcing factors, such as the so-called Dalton minimum of solar activity (1780-1840; see Anet et al., 2014) and several strong volcanic eruptions (The Unknown eruption of 1808-1809; see Guevara-Murua et al., 2014; Tambora, 1815; see Oppenheimer, 2003). To both of these external climate forcing factors, we must add the large-scale atmospheric circulation patterns, namely the North Atlantic Oscillation (Trigo et al., 2004), that, acting at different temporal scales, were probably responsible for the anomalies in terms of temperature and precipitation between the end of the $18^{\text {th }}$ century and the early $19^{\text {th }}$ century, in the region of Entre-Douro-e-Minho (Trigo et al., 2008; Fernández Férnandez et al. 2015, 2017).

\subsection{Impacts of meteorological phenomena on agricultural activity}

Our research shows that agricultural production in the Entre-Douro-e-Minho region was highly sensitive to short-term climatic variability and extreme weather events. The results reveal that temperature and precipitation deviations, from the baseline climate, adversely affected the quality and quantity of harvests and indirectly influenced the timing of crucial farm operations.

According to the Benedictine reports, the most common weather-related causes of lower yields or crop failures were: excessive rain in the harvest season (late August, September, and October), as reported in 1799 and 1810; low temperatures and excessive precipitation in late spring and summer (from June to September), as it was reported in 1809 and 1816 (especially for vineyards); and above average precipitation and high temperatures in winter and early spring (from December to April), as reported in 1807 and 1817 (mainly for wheat and rye crops). 
For the most part, these crop failures were sufficient to drive up grain prices, increase food insecurity and malnutrition, especially when combined with other adverse socio-economic conditions.

In fact, the movement of grain prices in five local markets in Entre-Douro-e-Minho (Figs. 7, 8,9) and the amount of tithes paid to three Benedictine monasteries of the same region (Fig. 10) seem to reflect fairly closely the harvest fluctuations.

As we can see in figures 7, 8, and 9, from 1798 to 1803 there was a slight increase in grain prices, which was particularly sharp in 1800 (very wet conditions for most of the previous year and the first four months of 1800) and in 1803 (drought and high temperatures in summer) (Figs. 2, 3, 4, 5).

Then, until 1808, grain prices declined (apparently, the loss of winter/spring crops in 1807 had no significant effect on prices) (Figs. 7, 8, 9). The examination of the tithe series reveals, in turn, that the triennium of 1804-06, as a whole, was a period of growth in the production of grain, compared to the previous two trienniums (Fig. 10). The favourable evolution of both indicators should be related, at least in part, to the absence of serious climate/weather anomalies during this period (Figs. 4, 5).

Thereafter, in 1809 and 1810, grain prices increased quite a lot, while the amounts paid as tithes dropped significantly (Figs. 7, 8, 9, 10). Much of this catastrophic situation was a direct result from the French Invasions (especially the second one, from February to May 1809, that passed through Entre-Douro-e-Minho), but the generally deficient harvests of these critical years, triggered, at least in part, by adverse weather conditions (wet and cold weather during the spring and summer of 1809 and persistent wet conditions in the autumn of 1810) also contributed considerably to it (Figs. 4, 5, 6).

After the French Invasions, crop production increased (Fig. 10) and grain prices slowly dropped until 1815 (Figs. 7, 8, 9), helped, certainly, by good grain growing conditions (except in 1814, which was marked by a very cold winter and spring and a very dry summer and early autumn) and good crops yields (except olive oil due to olive rust disease) (Figs. 4, 5, 6).

The 1816-17 period was an agricultural disaster, mainly due to a cold and rainy summer in 1816, followed by a dry and hot winter and spring in 1817 (Figs. 4, 5, 6). Crop failures caused big price increases for agricultural commodities (Figs. 7, 8, 9). 
Finally, from 1818 onwards, grain prices fell to low and stable levels, while agricultural growth increased (at least until 1822) (Figs. 7, 8, 9, 10).

FIGURE 7

Maize prices in Entre-Douro-e-Minho, 1798-1830

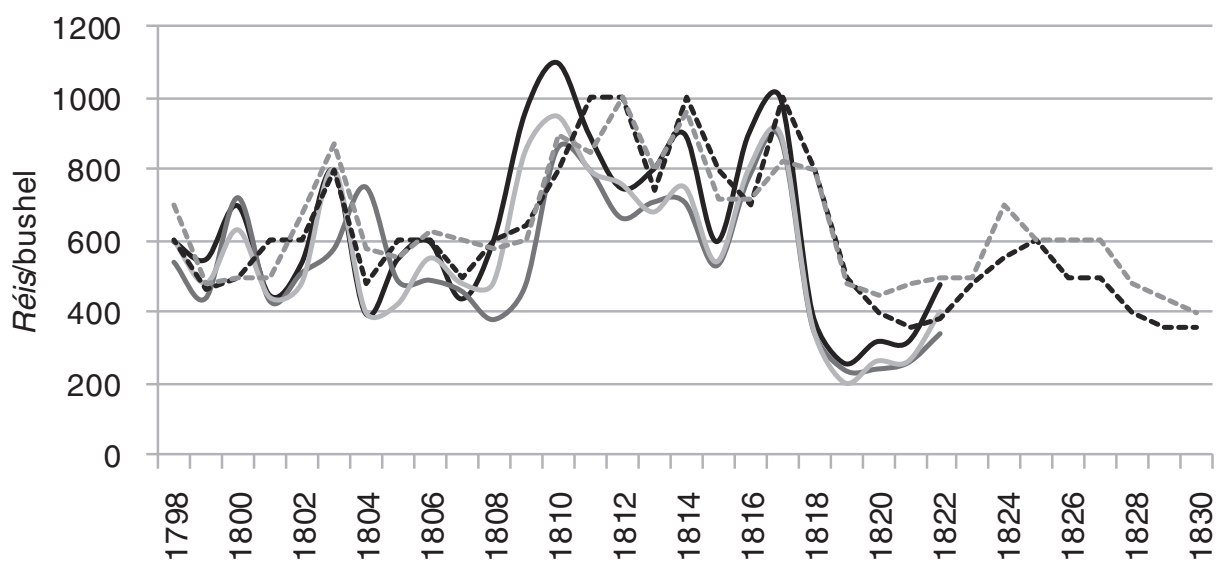

Caminha — V. Castelo — P. Lima ------ Tibães ------ Porto

Sources: Godinho (1955); Oliveira (1973); Silva (1993).

FIGURE 8

Rye prices in Entre-Douro-e-Minho, 1798-1830

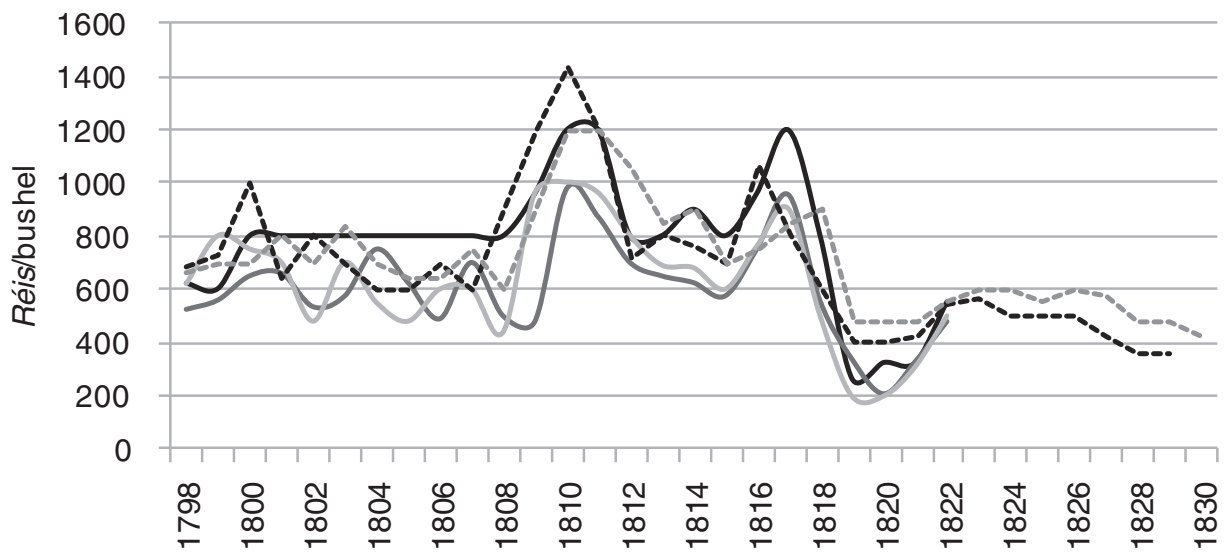

$\longrightarrow$ Caminha $\longrightarrow$ V. Castelo $\longrightarrow$ P. Lima ------Tibães ------Porto

Sources: Godinho (1955); Oliveira (1973); Silva (1993). 
FIGURE 9

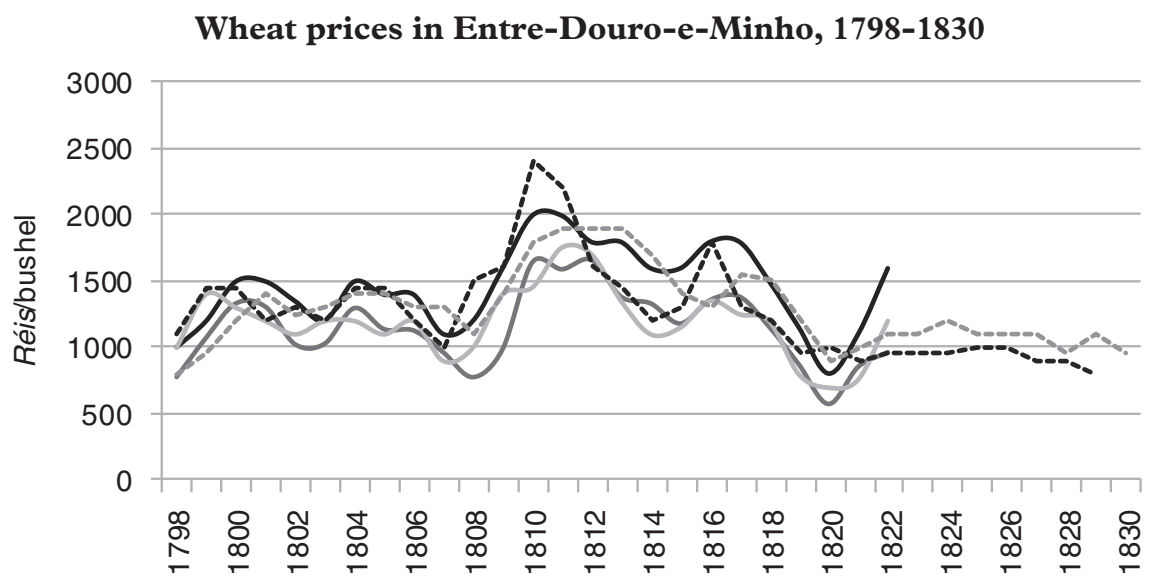

Caminha $\longrightarrow$ V. Castelo $\longrightarrow$ P. Lima ------Tibães ------Porto

Sources: Godinho (1955); Oliveira (1973); Silva (1993).

FIGURE 10

Grain tithe series in Entre-Douro-e-Minho, 1798-1822

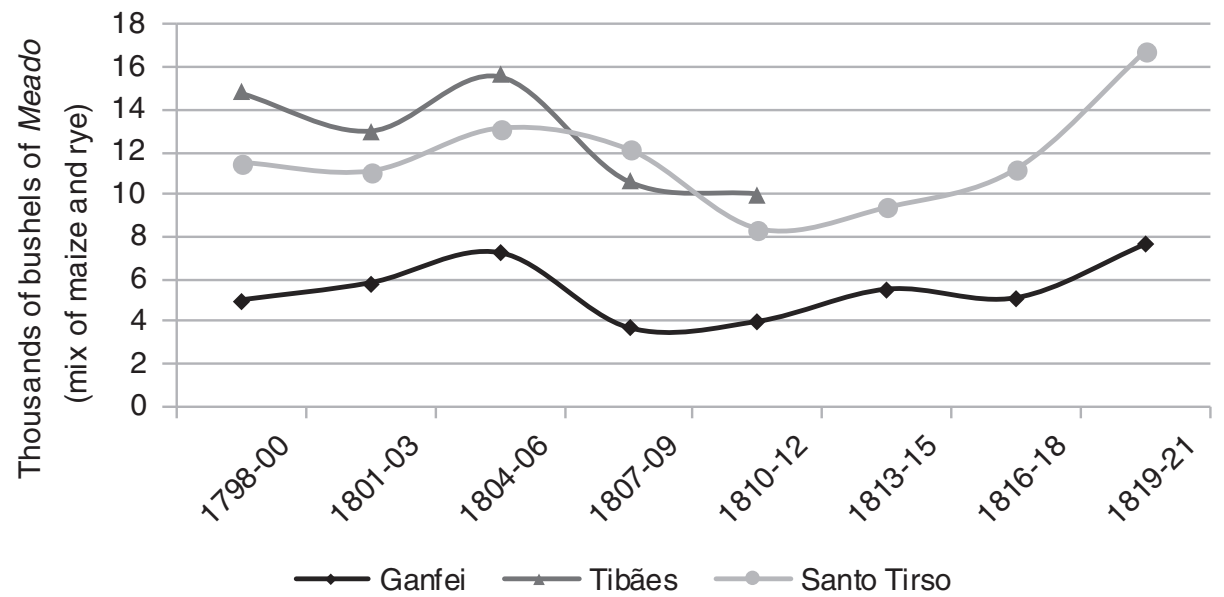

Sources: Oliveira (1979, 1982); Silva (1993).

\section{CONCLUSION}

In this study, we presented the first high-resolution index of temperature, precipitation, and agricultural production for the northwest of Portugal, during the period 1798-1830, 
based on qualitative weather records from two Benedictine diaries. The results obtained show that:

a) Documentary sources can be remarkably useful to reconstruct past climatic trends and extreme events from the pre-instrumental period. They also represent an important tool to investigate the vulnerability of pre-industrial societies to climatic extremes and natural disasters. From this point of view, the Benedictine diaries represent an exceptionally valuable new source which can be compared with other types of historical-climatological data. The information obtained from these diaries has a higher time resolution and provides more details than any other contemporary source in the examined area.

b) The climate in Entre-Douro-e-Minho, from 1798 to 1830, was characterized by a clear predominance of intense cold episodes, particularly in winter and spring. The precipitation patterns presented a highly irregular behaviour, alternating between drier and wetter periods, mostly in summer and winter, respectively.

c) Sharp deviations in meteorological conditions contributed to exacerbate the vulnerability of agricultural systems in the Entre-Douro-e-Minho region, especially when combined with other adverse natural and socio-economic factors. This study reveals that abrupt changes in temperature or in precipitation (quantity, timing, and intensity) had significant negative effects on crop productivity and food security, particularly evident in the years 1798-1803, 180712 , and 1816-17.

\section{ACKNOWLEDGEMENTS}

This work was supported by the Fundação para a Ciência e a Tecnologia (grant number $\mathrm{SFRH} / \mathrm{BD} / 105015 / 2014)$. The author is very grateful to the editors of this special issue (Ana Isabel Queiroz, Inês Gomes, and Inês Amorim) and to the anonymous reviewers of Historia Agraria for their careful reading of the manuscript and their many insightful comments and suggestions. Special thanks should be given to João Carlos Garcia and Sara Pinto for their useful and constructive recommendations, to Miguel Nogueira for his support with the cartography, and to Paulo Galante for thoroughly proofreading this text. Finally, the author gratefully acknowledges the financial support of the Transdisciplinary Research Centre "Culture, Space and Memory" with the translation. 


\section{REFERENCES}

Alberola, A. (2014). Los cambios climáticos: La Pequeña Edad del Hielo en España. Madrid: Cátedra.

Alcoforado, M. J. (2008). Fontes instrumentais e documentais para a reconstrução do clima do passado debatidas em conferência internacional. Finisterra, 43 (86), 157-59.

Alcoforado, M. J., Nunes, M. F., Garcia, J. C. \& TABorda, J. P. (2000). Temperature and Precipitation Reconstruction in Southern Portugal during the Late Maunder Minimum (AD 1675-1715). The Holocene, 10 (3), 333-40.

Alcoforado, M. J., Vaquero, J. M., Trigo, R. M. \& Taborda, J. P. (2012). Early Portuguese Meteorological Measurements (18 ${ }^{\text {th }}$ Century). Climate of the Past, (8), 35371 .

Alves, F. M. \& Pereira, G. M. (Ed. lit.) (2000). Memórias arqueológico-históricas do distrito de Bragança. T. 7. Bragança: CMB/IPM-MAB.

Amorim, I., Silva, L. P. \& Garcia, J. C. (2017). As cheias do rio Douro no Porto (Portugal) do século xviII. SÉMATA, Ciencias Sociais e Humanidades, (29), 185-217.

Amorim, M. N. (1987). Guimarães de 1580 a 1819: Estudo demográfico. Lisboa: Instituto Nacional de Investigacao Cientifica.

Anet, J. G., Muthers, S., Rozanov, E.V., Raible, E. V., Stenke, A., Shapiro, A. I., BrönNimann, S., Arfeuille, F., Brugnara, Y., BeER, J., Steinhilber, F., SCHMutz, W. \& PETER, T. (2014). Impact of Solar versus Volcanic Activity Variations on Tropospheric Temperatures and Precipitation during the Dalton Minimum. Climate of the Past, (10), 921-38.

BARRIENDOS, M. (1997). Climatic Variations in the Iberian Peninsula during the Late Maunder Minimum (AD 1675-1715): An Analysis of Data from Rogation Ceremonies. The Holocene, 7 (1), 105-11.

BARRIENDOS, M. (2005). Variabilidad climática y riesgos climáticos en perspectiva histórica: El caso de Catalunya en los siglos XVIII-XIX. Revista de Historia Moderna, (23), 11-34.

Barriopedro, D., Gallego, D., Álvarez Castro, M. C., García Herrera, R., Wheeler, D., Peña Ortiz, C. \& Barbosa, S. M. (2014). Witnessing North Atlantic Westerlies Variability from Ships' Logbooks (1685-2008). Climate Dynamics, 43 (34), 939-55.

Bokwa, A., Limanowka, D. \& Wibig, J. (2001). Pre-Instrumental Weather Observations in Poland in the $16^{\text {th }}$ and $17^{\text {th }}$ Century. In P. D. Jones, A. E. J. OGILvie, T. D. DAviES $\&$ K. R. BRIFFA (Eds.), History and Climate: Memories of the Future? (pp. 9-27). New York: Kluwer Academic/Plenum.

BragA, A. V. (1993). Curiosidades de Guimarães. Vol. III. Guimarães: Sociedade Martins Sarmento. 
BRÁZDIL, R., ÇERNUŞÁK, T., EZNí́KOVÁ, L. (2008). Weather information in the diaries of the Premonstratensian Abbey at Hradisko, in the Czech Republic, 1693-1783. Weather, (63), 201-07.

BRÁzDIL, R. \& Kiss, A. (2001). Daily Weather Observations at Košice, Slovakia in the Period 1677-1681. Meteorologický časopis, 4 (4), 3-14.

Brázdil, R., Pfister, C., WANNer, H., Storch, H. von \& Luterbacher, J. (2005). Historical Climatology in Europe:The State of the Art. Climatic Change, 70 (3), 363-430. BRÁZDIL, R., VALÁšEK, H. \& MACKOVÁ, J. (2003). Climate in the Czech Lands during the 1780s in Light of the Daily Weather Records of Parson Karel Bernard Hein of Hodonice (Southwestern Moravia): Comparison of Documentary and Instrumental Data. Climatic Change, 60 (3), 297-327.

Brázdil, R., VAlÁŠEK, H., Chromá, K., DolÁK, L., ŘEzníčKová, L., Bělínová, M., VALÍK, A. \& ZaHRADNíčEK, P. (2019). The Climate in South-East Moravia, Czech Republic, 1803-1830, Based on Daily Weather Records Kept by the Reverend Šimon Hausner. Climate of the Past, 15 (4), 1205-22.

Camuffo, D., Bertolin, C., Barriendos, M., Domínguez Castro, F., Cocheo, C., Enzi, S., SGhedoni, M., Della Valle, A., Garnier, E., Alcoforado, M. J., Xoplaki, E., Luterbacher, J., Diodato, N., Maugeri, M., Nunes, M. F. \& Rodríguez, R. (2010). 500-YearTemperature Reconstruction in the Mediterranean Basin by Means of Documentary Data and Instrumental Observations. Climatic Change, 101 (1), 16999.

Camuffo, D., Bertolin, C., Diodato, N., Cocheo, C., Barriendos, M., Domínguez Castro, F., Garnier, E., Alcoforado, M. J. \& Nunes, M. F. (2013). Western Mediterranean Precipitation over the Last 300 Years from Instrumental Observations. Climatic Change, 117 (1-2), 85-101.

Coutinho, M. (2011). Notícias das guerras napoleónicas: Dietário do Mosteiro de Santa Maria de Pombeiro (1807-1816). Porto: Deriva.

David, H. (1992). As crises de mortalidade no concelho de Braga (1700-1880).Vol. 1. PhD thesis. Porto: Universidade do Porto.

Dias, G. (1995). O órgão do mosteiro beneditino de Pombeiro (Felgueiras). Revista de História, (13), 119-30.

Domínguez Castro, F., García Herrera, R. \& Vaquero, J. M. (2015). An Early Weather Diary from Iberia (Lisbon, 1631-1632). Weather, 70 (1), 20-24.

Domínguez Castro, F., Ribera, P., García Herrera, R., Vaquero, J. M., Barriendos, M., Cuadrat Prats, J. M. \& Moreno, J. M. (2012). Assessing Extreme Droughts in Spain during 1750-1850 from Rogation Ceremonies. Climate of the Past, 8 (2), $705-$ 22.

Druckenbrod, D. L., Mann, M. E., Stahle, D. W., Cleaveland, M. K., Therrell, M. D. \& SHugarT, H. H. (2003). Late-Eighteenth-Century Precipitation Reconstructions 
from James Madison's Montpelier Plantation. Bulletin of the American Meteorological Society, (84), 57-72.

Fagan, B. (2002). The Little Ice Age: How Climate Made History 1300-1850. New York: Basic Books.

FERnÁNDEZ Cortizo, C. (2016). La pequeña edad de hielo en Galicia: Estado de la cuestión y estudio histórico. Obradoiro de Historia Moderna, (25), 9-39.

Fernández Fernández, M. I., Gallego, M. C., Domínguez Castro, F., Trigo, R. M., García, J. A., Vaquero, J. M., Moreno, J. M. \& Castillo, J. (2014). The Climate in Zafra from 1750 to 1840: History and Description of Weather Observations. Climatic Change, 126 (1-2), 107-18.

Fernández Fernández, M. I., Gallego, M. C., Domínguez Castro, F., Trigo, R. M. \&VAquero, J. M. (2015). The Climate in Zafra from 1750 to 1840: Precipitation. Climatic Change, 129 (1-2), 267-80.

Fernández Fernández, M. I., Gallego, M. C., Domínguez Castro, F., Trigo, R. M. \& VAquero, J. M. (2017). The Climate in Zafra from 1750 to 1840: Temperature Indexes from Documentary Sources. Climatic Change, 141 (4), 671-84.

Ferreira, H. (Dir.) (1942a). O Clima de Portugal. Fascículo I:Valores médios dos elementos climáticos no periodo 1901-1930. Lisboa: Observatório do Infante D. Luiz.

Ferreira, H. (Dir.) (1942b). O Clima de Portugal. Fascículo II: Entre-Douro-e-Minho. Lisboa: Observatório do Infante D. Luiz.

Fragoso, M., Carraça, M. G. \& Alcoforado, M. J. (2018). Droughts in Portugal in the $18^{\text {th }}$ Century: A Study Based on Newly Found Documentary Data. International Fournal of Climatology, 38 (15), 1-20.

Fragoso, M., Marques, D., Santos, J. A., Alcoforado, M. J., Amorim, I., Garcia, J. C., Silva, L. P. \& Nunes, M. F. (2015). Climatic Extremes in Portugal in the 1780s Based on Documentary and Instrumental Records. Climate Research, 66 (2), 141-59. García Herrera, R., Können, G. P., Wheeler, D. A., Rosario Prieto, M., Jones, P. D. \& KoeK, F. B. (2005). CLIWOC: A Climatological Database for the World's Oceans 1750-1854. Climatic Change, 73 (1), 1-12.

GERTISSER, R. \& SELF, S. (2015). The Great 1815 Eruption of Tambora and Future Risks from Large-Scale Volcanism. Geology Today, 31 (4), 132-36.

Godinho, V. M. (1955). Prix et Monnaies au Portugal, 1750-1850. Paris: Librairie Armand Colin.

GonZÁlez FeRnÁndeZ, J. M. (2000). Crisis de subsistencias y epidémicas en las villas de Vigo y Bouzas (1680-1820). Boletín del Instituto de Estudios Vigueses, (6), 87-105.

Guevara-Murua, A., Williams, C. A., Hendy, E. J., Rust, A. C. \& Cashman, K. V. (2014). Observations of a Stratospheric Aerosol Veil from a Tropical Volcanic Eruption in December 1808: Is this the "Unknown" 1809 Eruption? Climate of the Past, (10), 1707-22. 
Hirano, J. \& Mikami, T. (2008). Reconstruction of Winter Climate Variations during the $19^{\text {th }}$ Century in Japan. International fournal of Climatology, 28 (11), 1423-34.

Lamy, A. (1977). Monografia de Ovar. Ovar:Tipografia Guerra.

Le Roy Ladurie, E. (2017). Historia humana y comparada del clima. México, DF: Fondo de Cultura Económica.

Lorrey, A. M. \& Chappell, P. R. (2016). The "Dirty Weather" Diaries of Reverend Richard Davis: Insights about Early Colonial-Era Meteorology and Climate Variability for Northern New Zealand, 1839-1851. Climate of the Past, 12 (2), 553-73.

LosAdA, M. (2008). Documentación histórica e clima. In F. DíAz-Fierros (Coord.), Historia da meteoroloxía e da climatoloxía de Galicia (pp. 143-83). Santiago de Compostela: Consello da Cultura Galega.

Luterbacher, J., Dietrich, D., Xoplaki, E., Grosjean, M. \& Wanner, H. (2004). European Seasonal and Annual Temperature Variability, Trends, and Extremes Since 1500. Science, 303 (5663), 1499-1503.

Mann, M. E., Gille, E., Bradley, R. S., Hughes, M. K., Overpeck, J., Keimig, F. T. \& Gross, W. (2000). Global Temperature Patterns in Past Centuries: An Interactive Presentation. Earth Interactions, 4 (4), 1-29.

Medeiros, C. A. (Dir.) (2005). Geografia de Portugal: O ambiente físico. Lisboa: Círculo de Leitores e Autores.

MetzGer, A. \& TABEAUd, M. (2017). Reconstruction of the Winter Weather in East Friesland at the Turn of the Sixteenth and Seventeenth Centuries (1594-1612). Climatic Change, 141 (2), 331-45.

Monteiro, A. (Coord.) (2005). Atlas agroclimatológico do Entre Douro e Minho: Relatório do Projecto POCTI/GEO/14260/1998. Porto: Universidade do Porto.

Nunes, M. F. (2003). As observações meteorológicas na Academia das Ciências: Uma leitura científica de Lamego (1770-1784). In A. PINTO DE CASTro (Coord.), Alcipe $e$ as luzes. Lisboa: Colibri.

Oliva, M., Ruiz Fernández, J., Barriendos, M., Benito, G., Cuadrat, J. M., Domínguez Castro, F., García Ruiz, J. M., Giralt, S., Gómez Ortiz, A., HernánDeZ, A., López Costas, O., López Moreno, J. I., López Saez, J. A., Martínez CoRtizas, A., Moreno, A., Prohom, M., Saz, M. A., Serrano, E., Tejedor, E., Trigo, R., Valero-Garcés, B. \&Vicente-Serrano, S. M. (2018). The Little Ice Age in Iberian Mountains. Earth-Science Reviews, (177), 175-208.

OliveirA, A. (1973). Elementos para a história dos preços na região bracarense (16801830). Bracara Augusta, (xxv-XXvi), 125-41.

Oliveira, A. (1979). A Abadia de Tibães 1630/80-1813: Propriedade, Exploração e Produção Agrícolas no Vale do Cávado durante o Antigo Regime. PhD thesis. Porto: Universidade do Porto. 
Oliveira, A. (1982). Contabilidades monásticas e produção agrícola durante o Antigo Regime: Os dízimos do Mosteiro de Santo Tirso, 1626-1821. Santo Tirso: Câmara Municipal de Santo Tirso.

Oliveira, A. (1996). As crises agrícolas de Entre Douro e Minho nos finais do Antigo Regime. In III Fornadas de Estudo Norte de Portugal-Aquitânia, Actas (pp. 249-78). Porto: Universidade do Porto/Centro de Estudos Norte de Portugal-Aquitânia. OliveirA, A. (2007). Clima e colheitas em Portugal (1500-1850). In M. F. ReIs (Coord.), Rumos e escrita da história. Estudos em homenagem a A. A. Marques de Almeida (pp. 107-40). Lisboa: Colibri.

OpPENheimer, C. (2003). Climatic, Environmental and Human Consequences of the Largest Known Historic Eruption: Tambora Volcano (Indonesia) 1815. Progress in Physical Geography: Earth and Environment, 27 (2), 230-59.

PARker, G. (2014). Global Crisis:War, Climate Change and Catastrophe in the Seventeenth Century. New Haven/London:Yale University Press.

Pauling, A., Luterbacher, J., CAsty, C. \& Wanner, H. (2006). Five Hundred Years of Gridded High-Resolution Precipitation Reconstructions over Europe and the Connection to Large-Scale Circulation. Climate Dynamics, 26 (4), 387-405.

Pfister, C. (2005). Weeping in the Snow: The Second Period of Little Ice Age-type Impacts, 1570-1630. In W. Behringer, H. Lehrmann \& C. Pfister (Eds.), Kulturelle Konsequenzen der Kleinen Eiszeit: Cultural Consequences of the "Little Ice Age" (pp. 3186). Gottingen: Vandenhoeck \& Ruprecht.

Pfister, C. (2015). Weather, Climate and the Environment. In H. ScotT (Ed.), The Oxford Handbook of Early Modern European History, 1350-1750: Peoples and Place (pp. 70-93).Vol. I. Oxford: Oxford University Press.

Pfister, C., Brázdil, R., Glaser, R., Bokwa, A., Holawe, F., Limanowka, D., Kotyza, O., Munzar, J., Rácz, L., Strömmer, E. \& Schwarz-Zanetti, G. (1999). Daily Weather Observations in Sixteenth-Century Europe. Climatic Change, 43 (1), 111-50. RaICICH, F. (2008). Some Features of Trieste Climate from an Eighteenth Century Diary (1732-1749). Climatic Change, 86 (1-2), 211-26.

Rodrigo, F. \& BARRIENDOS, M. (2008). Reconstruction of Seasonal and Annual Rainfall Variability in the Iberian Peninsula $\left(16^{\text {th }}-20^{\text {th }}\right.$ Centuries) from Documentary Data. Global and Planetary Change, 63 (2-3), 243-57.

SANDERSON, M. G. (2018). Daily Weather in Dublin 1716-1734: The Diary of Isaac Butler. Weather, 73 (6), 179-82.

SEPúlvedA, C. (1913). História orgânica e politica do exército português. Vol. x. Lisboa: Imprensa Nacional.

Silva, A. \& Figueiredo, F. (2018). "Preces a Nosso Senhor para dar bom tempo". Preces e procissões de penitência da Ordem Franciscana Secular de Coimbra (séculos XVIII-XIX). História. Revista da FLUP, 8 (1), 54-77. 
Silva, C. M. T. (1993). O Mosteiro de Ganfei: Propriedade, produção e rendas no Antigo Regime (1629-1683 e 1716-1822). Master thesis. Porto: Universidade do Porto.

Silva, L. P. (2017). O clima do Noroeste de Portugal, no século XVIII, através das preces e procissões Pro Pluvia e Pro Serenitate. In A. Alberola (Ed.), Riesgo, desastre y miedo en la península Ibérica y México durante la Edad Moderna (pp. 151-82). Alicante: Universitat d'Alacant/El Colegio de Michoacán.

Silva, L. P. (2019). O clima do Noroeste de Portugal (1600-1855): Dos discursos aos impactos. PhD thesis. Porto: Universidade do Porto.

Stocker, T., Quin, D., Plattner, G.-K., Tignor, M., Allen, S., Boschung, J., Nauels, A., XIA, Y., BeX, V. \& Midgley, P. (Eds.) (2013). Climate Change 2013:The Physical Science Basis. Contribution of Working Group I to the Fifth Assessment Report of the Intergovernmental Panel on Climate Change. Cambridge: Cambridge University Press.

Taborda, J. P., Alcoforado, M. J. \& Garcia, J. C. (2004). O clima do Sul de Portugal no século XVIII: Reconstituição a partir de fontes descritivas e instrumentais. Lisboa: Centro de Estudos Geográficos.

Trigo, R. M., Pozo-Vázquez, D., Osborn, T. J., Castro-Díez, Y., Gámiz-Fortis, S. \& Esteban-ParRa, M. J. (2004). North Atlantic Oscillation Influence on Precipitation, River Flow and Water Resources in the Iberian Peninsula. International fournal of Climatology, (24), 925-44.

Trigo, R. M., Vaquero, J. M., Alcoforado, M. J., Barriendos, M., Taborda, J. P., GarCía-HERRERA, R. \& LuTERBACHER, J. (2008). Iberia in 1816, the Year without a Summer. International fournal of Climatology, 29 (1), 99-115.

Walsh, R. P. D., Glaser, R. \& Militzer, S. (1999). The Climate of Madras during the Eighteenth Century. International Fournal of Climatology, 19 (9), 1025-47.

White, S., Pfister, C. \& Mauekshagen, F. (Eds.) (2018). The Palgrave Handbook of Climate History. London: Palgrave Macmillan.

Zhang, X. Z., Ge, Q. S., FANG, X. Q., Zheng, J.Y. \& FeI, J. (2013). Precipitation Variations in Beijing during 1860-1897 AD Revealed by Daily Weather Records from the Weng Tong-He Diary. International fournal of Climatology, 33 (3), 568-76. 